\title{
EXPERIMENTAL AND CLINICAL STUDIES ON CERVICAL LYMPHOGRAPHY
}

\author{
By \\ JUN NONOYAMA \\ From the Department of Oto-Rhino-Lalyngology, School of Medicine, \\ Mie University (Director: Prof. Yashuro Miyoshi)
}

Lymphography of the cervical lymphatic systen. was performed experimentally and clinically for the diagnostic purposes in the head and neck surgery.

The results were as follows:

1) Observations of the cervical lymphograms at different.

Stages after injection of a contrast medium in dogs. The visualization of the cervical lymphatic vessels was of the most clear at 2 hours after injection and gradual disappearance was up to 24 hours thereafter. The lymph nodes were demonstrated most finely at 24 hours showing the typical homogeneous reticular patterns.

2) The histopathological investigation of the cervical nodes in dogs.

Upto 6 months after injection, mild nonspecific inflammatory changes occurred in the nodes due to the foreign body reaction of the contrast medium and lymphocytes were hoted to be decreasing grodually in the nodes.

But after 6 months, the fatty droplets phagocytized by giant cells were eliminated, lymphocytes increased in number. At $9 \sim 12$ months stage after injection, the tissues of the nodes showed normal histology.

3) The fat embolism following the cervical lymphography in dogs.

Although the fat embolism following the cervical lymphography in dogs may not be prevented completely, there is no risk of mentioned above following the cervical lymphography if the injec- tion is performed with the greatest care of the volume and the speed.

4) Clinical investigation of cervical lymphography.

Cervical lymphography was performed in 24 patients exclusively via the single retroauricular approach.

The visualizations of the normal cervical lymphatic system were made by the lymphography.

In the cases sofar experienced, abnormal changes were the following:

A) The passage disorder or blockage of lymphatic vessels

a) Increase of Lynphatic capillaries in $\mathrm{nu}$ mber and reticular changes of lymphatic vessels

b) The changes of lymphatic vessels (rupture, dilatation, blockage, tortuosity and collateral formation)

B) Abnormal changes of lymph nodes

a) Moth-eaten appearance

b) Gohst-like appearance

c) Homogeneous filling or non-structure

C) Normal but apparently abnormal lymph nodes

a) Pseudo-moth-eaten appearance

b) Central filling defect

Cervical lymphography is a valuable procedure for the diagnosis of malignant tumors in regions of head and neck, although it has a limited value for detecting an early small lesion of the lymphatic system. 


\title{
頸部リンパ系造影の実験的 \\ ならびに臨床的研究
}

\author{
三重県立大学医学部耳雤咽喉科学教室（主任:三吉康郎教授） \\ 野々
}

目次

第 1 篇 正常犬頸部リンパ系造影法

第1章 緹譣

第2 章 奏駼動物ならびに罢験力法

A 正常大頸部りンパ采レ線像の経時的変化

B 摘出りンパ節内造影剤分布の経㭙的観察

第 3 章 実験成結

A 正常犬頙部りンパ系造影像

B 正常犬䫂部りンパ系レ楾像の経時的变化

C 摘出リンパ節内造影用分布のレ線学的变化 ( レ楾执大影撮)

符 4 章 総括ならびに考按

第 5 章 結諭

第 2 篃大頸部造影リンパ節の病理維緎学的检索

第 1 章緒覦

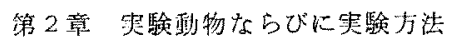

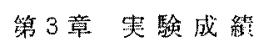

A リンパ節組䋭内に拈ける造影剂分布状態の紸 時的変化

Byンパ系細胞撒成の経時的变化

C 細網䒺細胞䈷成の経㭙的变化

Dリンパ節組織内膠原線維化の経時的夜化

第 4 章 総括ならびに教按

第 5 壁 結馀

第3篇 正常犬鰂部りンパ系造影にともな5汒幽塞栓 症の問題

第 1 章 緒
第 2 竟 实験動物ならびに实験方法

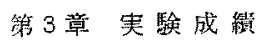

第4 章 総括ならびに考技

第 5 影 結諭

第 4 篇 ヒト頚部りンパ系造影法

第 1 点犁諸命

第 2 章 実験方法
$\mathrm{A}$ 術前処埴
B ヒト頚部リンパ系造影法の手技
C 撮影装置肪よび撮影条件
$\mathrm{D}$ 撮影力问

第3章史歌成絈
A 正常頸部りンパ系造影像
B 異常頸部リンパ系造影隻

第 4 竟 総括ならびに考按

第 5 章 結馀

緒言

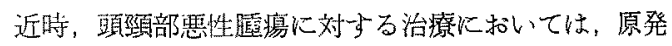
栄の除去とともに頸部転移の治療に関しては非常なる考 虑が払わ机ているのが現状である。一方頸部りンパ節転 移の彰盺法については触診の外に最近では ${ }^{198} \mathrm{Au}$ ーシン チグラムやや超音波診断法 2)も行われているがな沶一 般的には触診法のみに依存している場合が多い，頸部部 清術を行らに当つて，その適応や術式を決定するため，

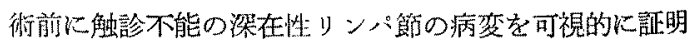
する手段としてリンパ系造影法を頭頸部領域のリンバ系 飞試みよらとしたのが本研窥の目的である。

第1篇 正常犬頸部リンパ系造影法

\section{第1章 緒 論}

リンパ系造影法に扣けるレ線像の経時的な変化やりン

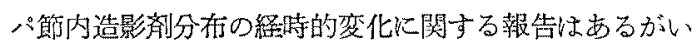
づれも簡略にすざ詳細を欠いている。私は本研究を実施 するに当りまず基䝪的研究として正常成犬に対して頸部
リンパ系造影法を行い，そのレ線像扰よびリンハ節内造 影刻分布状熊を6カ月にわたり詳緗に観察し，その変化 老経時的追求した。

第 2 章 実験動物ならひに実験方法

健常成大（体重 6 10kg）を用いる．使用頭数はレ 


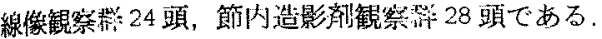

帘験操作はイソミタールの腹腔内注入麻酔の下に拱施 する.すなわら体重 $1 \mathrm{~kg}$ につきイソミタール 0.05grを

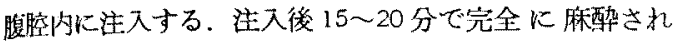

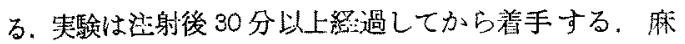
醉不完全の場合心麻型の深度に応じて適宜追加注射を行 5 .

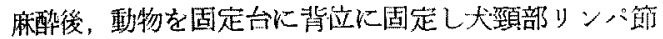
に造影用を注入する。リンバ節内え造影剂を注入するに あたつてはりンパ系を事的によく確馀しておく必要があ る、私はリン・系の撰択性染色効果が大である Patent Blue V D $11 \%$ 水溶液学用いた. 寸なわらその $0.2 \mathrm{cc}$ 犬の下口唇に注入する，色素注入後䄪 10 分間注射部位 を中枢に向つてマッサージしその後の手技を容易ならし

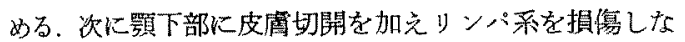
いように留意しながら青染した顎下リンハ節を求める。 篢下部リンパ節は色袁を注入することにより数個の顎下 部リンパ節をよく確認し得る，次いで造影剖を1個の顕 下部リンパ節に注入する，注入する造影郕として私は Popiodol を使用した，注入量はリンパ節の大小によつ て差違があるが $2.0 \mathrm{cc}$ 前後で注入速度は全量注入する に䄪 1 時間を要寸る，造影削注入終了後，上線撮影を施 行余る.

A 正常犬頸部リンパ系レ線像の絽特的観察 造影剂注入後 1 時間， 2 時間， 24 時間， 48 時間， 20 日， 1 力月， 2 力月， 3 力月，4力月， 5 力月， 6 力月て

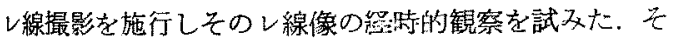
の撮影荠置および撮影条件沈次の如くである.

a) レ線発生装置: 東芝 $\mathrm{KXO}-8$

b) 管球: DRX-70 ロータノート 焦点 $2 \times 2 \mathrm{~mm}$

c) 散乱線除去法：多重シヤッター 6: 1MS グリ $\% ト$

d) 增感紙: 極光整 FS

e) フイルム:さくら X-レイ・タイプY

f) 管電生: $55 \sim 60 \mathrm{kvp}$

g) 管電堍: $50 \sim 100 \mathrm{~mA}$

h) 嚗射時間：0.2 0.15秒

i ）焦点フイルム間距泡: $100 \mathrm{~cm}$

撮影力向

a) 前後 面

b) 側 面

B 摘出リンパ節内造影威分布の路寺的観察（レ線 扰大撮影)

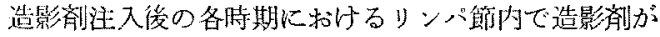
どの上らな態度をとつて存在し，造影剂注入後の各封期 に扣けるリンパ節像がいかにして得られるかを道求する 目的で，造影剂注入啳 1 時間，24時間，20日，1力月， 2 力月， 3 力月， 4 力月， 5 力月， 6 力月，の各時期汇区 分して造影リンバ節を摘出し節内の油性造影剂分有状態 をレ線学的に観察する.

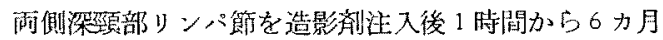
までの各時期に摘出し，10\%ホルマリン溶液にて固定す

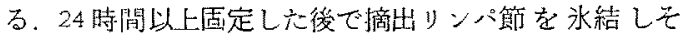
の中心部奇含めて約 $3 \mathrm{~mm}$ の學さの切片となし直接抬大 撮影を施行する。掂大撮影堎置および撮影条件は次の如 くである。

a) 倍率: 2 倍

b）乙線発生装啨：東芝 $\mathrm{KXO}-15$

c) 管球: DRX-81 ロータノード $0.3 \times 0.3 \mathrm{~mm}$

d）散乱線除去法：多重シャッター

e) 嵝感紙: 使用せず（ノンスクリーン）

f) 管雷价: $49 \mathrm{kvp}$

g) 管電流: $30 \mathrm{~mA}$

h) 懪射時間: 1.5 秒

i）焦点フイルム間距離: $100 \mathrm{~cm}$

j) 焦点被写体間距离: $50 \mathrm{~cm}$

以上の如さ直接应大撮影飞つて得られた各時期におけ る両側深致部リンパ節レ線像により節内造影剂の分布状 態老篗璂する。

リン・節内造影凃分布度の算出法

直接执大撮影によつて得られた写真よりリンバ節横断 面積と造影卻分布面積を面積計にて測定し雨都の面積の 比索 (100 分率) を算出して節内造影剂分布度とする。

寸なわ方

$$
\text { 節内造影用分布度 }=\frac{\text { 造影剂分布面積 }}{\text { ソン八節盽面積 }} \times 100(\%)
$$
とする。

\section{第 3 章 実 跧 成 綪}

A 正常犬頸部りンパ系造影像

$11 \%$ Patent blue $\mathrm{V}$ を犬の下口唇に注入し顎下部り ンパ節群の1 つK造影成(Popiodol) を注入して得られ た正常犬頸部リンパ系造影像についてのヘる。.

顎下部りンパ節は下顎骨佮と正中線の中間で䦭钼筋の 直下に存在し，小豆大ないし小指頭大のリンパ節が2

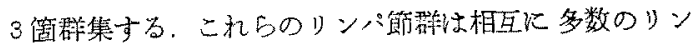
：管（輸出管及び輸入管）により㙞絡され，更に各りン 
八節はそれぞれ同側の桜頸部りン゙パ節に輸入管を送る。

これらのリンス管は括和むね蛇行して走向する。

深頸部りンパ節は颚下腺の下方で胸鎖乳突筋の内傊飞 位し，知頭の外側後方に接し第 $I \sim \mathbb{1}$ 形椎の高さに一致 して存在し，外形は紡鉦形ないし舆棈円形で拇指頭大で ある. 正面像では左右一対で規則正しく対称形汇存在す る.
その輸入管は同側の顎下部りン次節群より受け，輸出

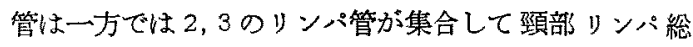
管を形成する．頸部りンパ総管は気管の後上オより前下 万に向って真直くに下向する。

他方，輸出管は项椎正中部汇向つて一旦上向し頸椎正 中部に到ると下向して区対側の深頸部リンパ節へ流入す る. (第 1 図)

第 1 图正常犬頚部りンパ系

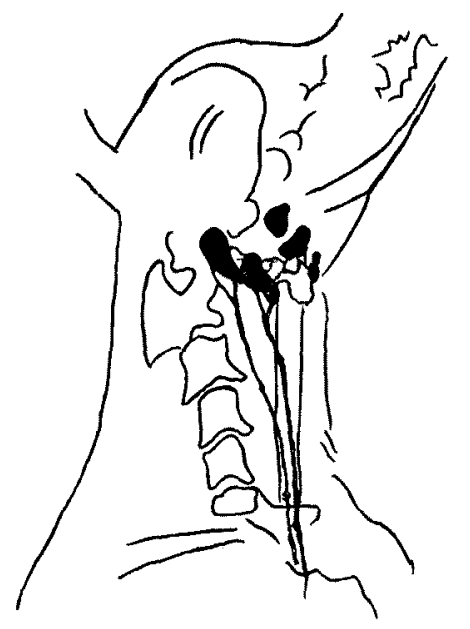

B 正常犬頊部リンパ系レ線像の絽㭙的変化 前章に述べた実験方法により正常成犬 24 頭について 頸部リンパ系レ線像の経时的变化を観察する.

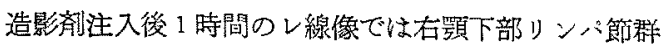
の一つに造影用が注入されると顎下部リンパ節群全部に 造影剤は充满し各リンパ節群を連䅂するリンパ管拉よび 同側の深頸部リンパ節とそれ机向らリンパ管とが明瞭に 造影される. 更に同(側のリン・節より反対(側の媣頸部り ンパ節へ向わんとするリンパ管は明かであるが反詨側深

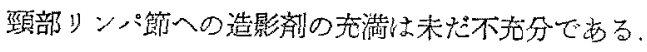

造影冏注入啳 2 時間のレ線像では造影剂注入後 1 時閍 では明かでなかかた反刘側の湀頸部りンパ節も明膫であ り，各リンパ筑を連絡するリンパ管と深頸部リンパ節上 り下向する頸部リンパ総管をも芜影可能となる，この㭙 期のリンパ系レ線像と奏際沉色素で染まつたりンバ系と の関係を比較してみると造影像が頸部リンパ系の解剖学 的構成を正確に表現する事を確認し得る（第 2 图)

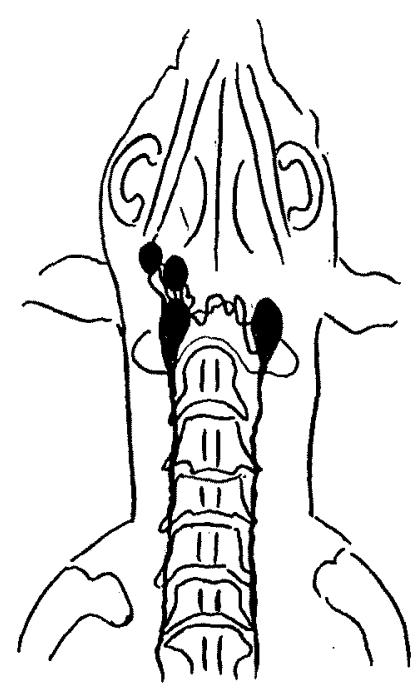

造影滆注入後 24 時間のレ線像ではリンハ管の造影像 はすでに消失して括り左右の深頸部リンパ節は造影剂が

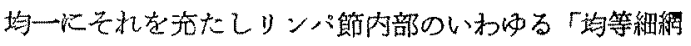
構造」の観察も可能で辺緑輸鄎の判然とした円形留形あ るいは紡鍾形の形態を有する陰影として表現される。

(第 3 図)

造影剂注入後 48 時間のレ線像ではりンハ節内部の造 影剂は未だ良く㴖溜し左有の深项部りンハ節以「均等紐 網就造」をよく保つて完全造影を呈している。.

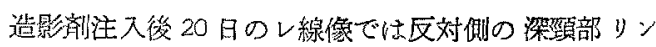
公筑がわずかに吸収されている兆候をみせているが同側 のリンパ節群さすべて时睽な造影像を認め得る。

造影刘注入彴 1 力月のレ線像ではすでに所々造影剂け

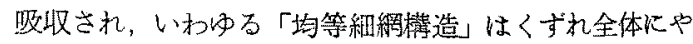

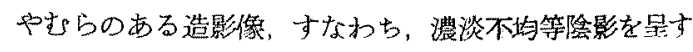
ろ. (第 4 图)

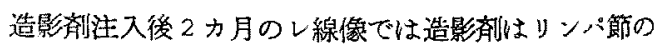


第 2 図造影剂注入後 2 時間
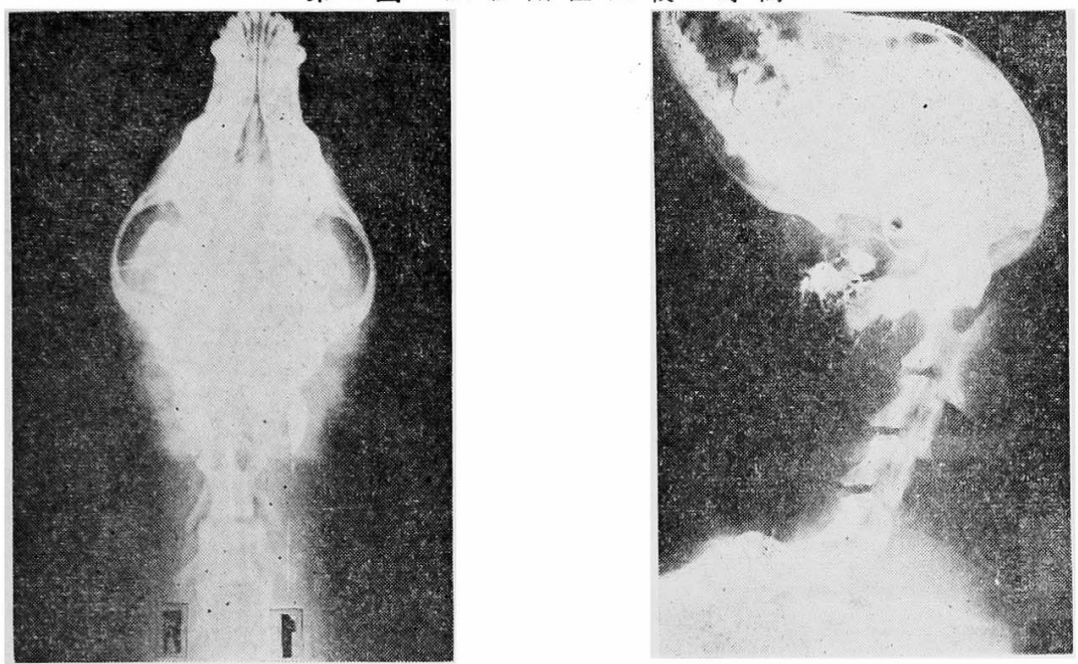

第 3 図造影剤注入後 24 時間
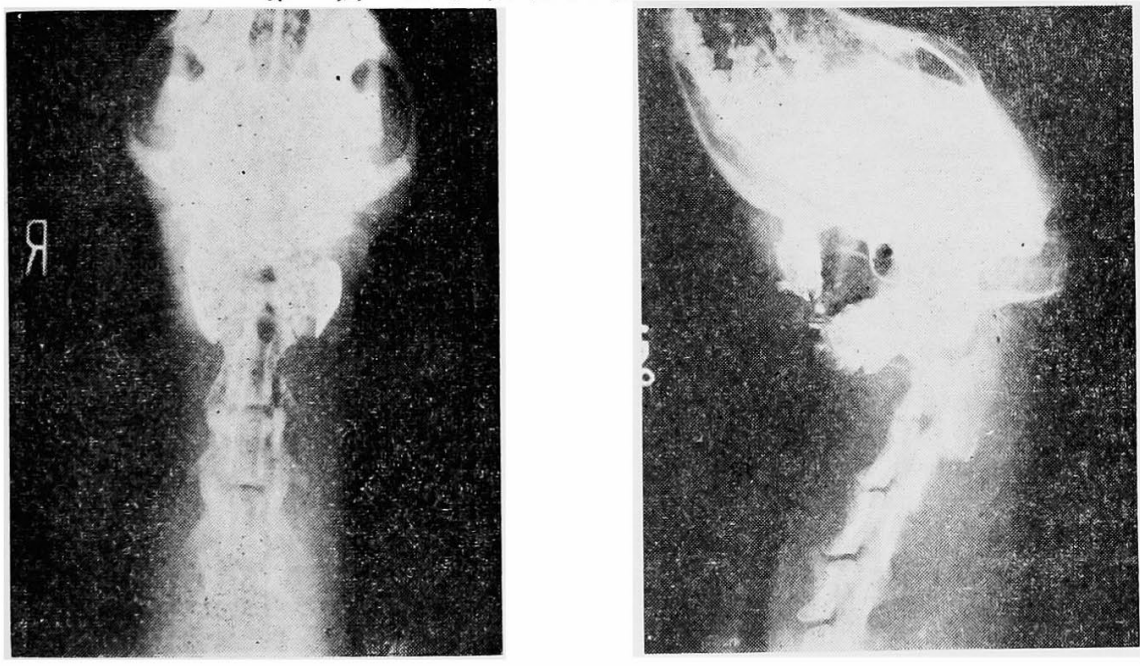

第 4 図造影剤注入後 1 力月
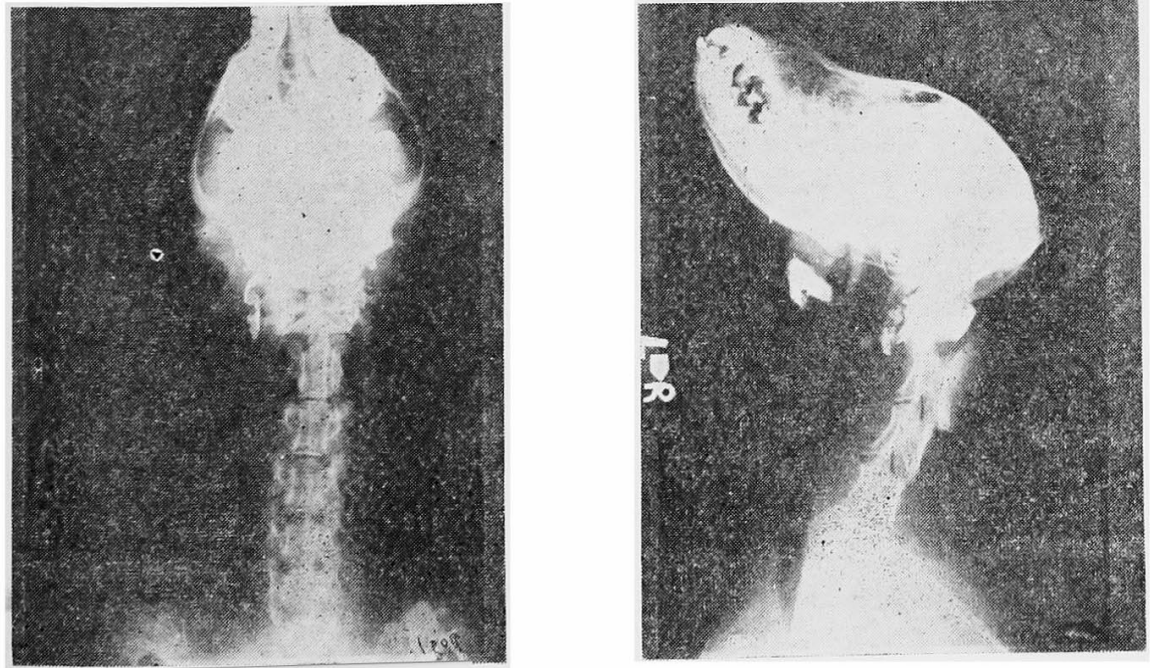
第 5 図造影剂注入後 2 力月
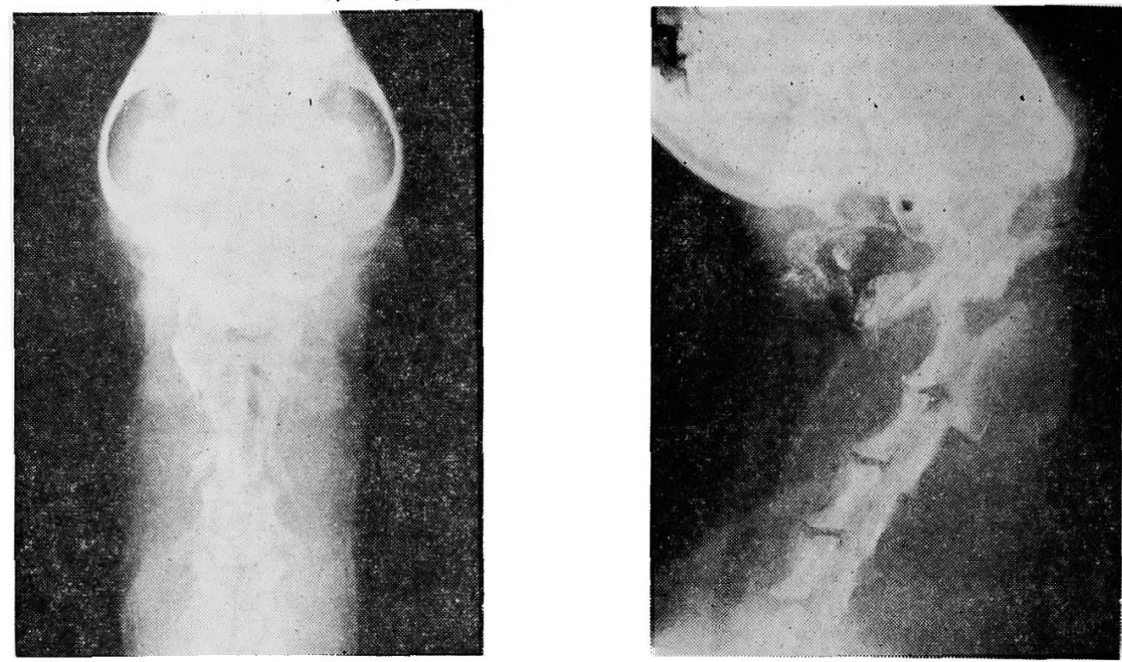

第 6 図造影剂注入後 4 力月
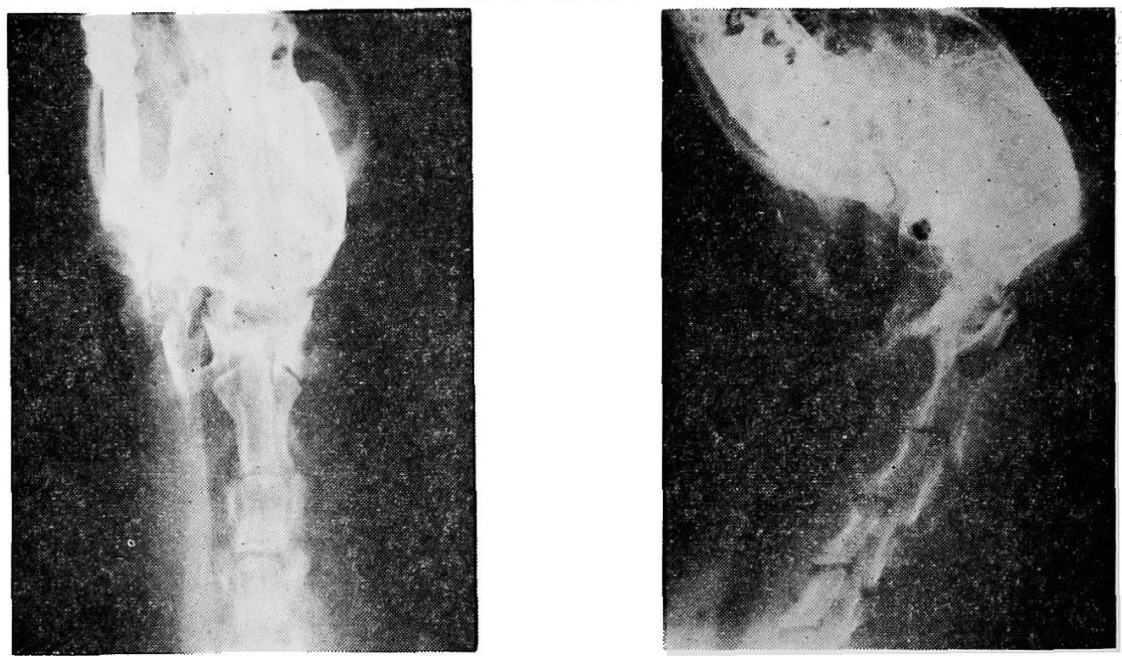

第 7 図造影剂注入後 6 力月
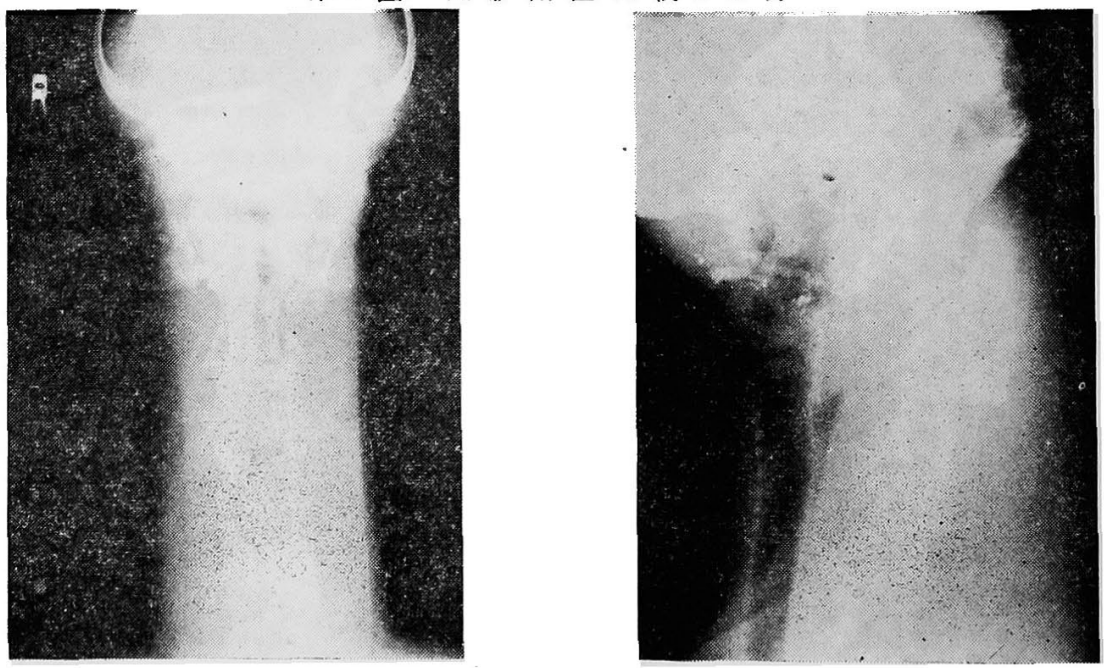
第 8 図造影剤注入後 1 時間

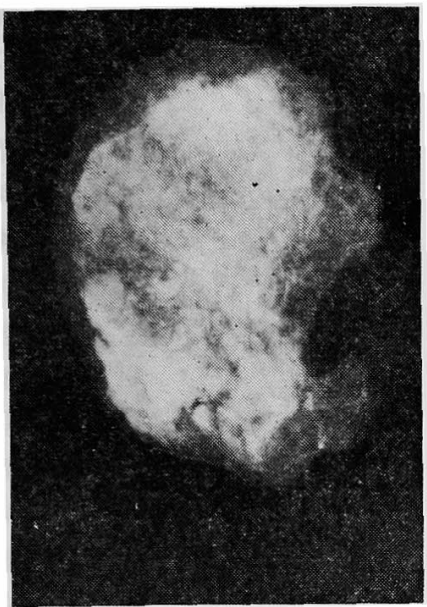

右

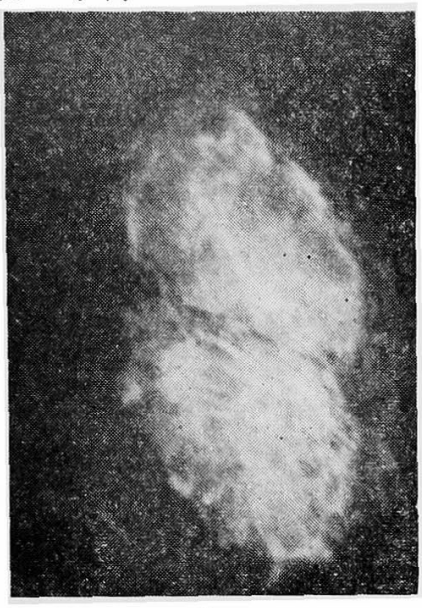

左

第 9 図造影剂注入後 24 時間
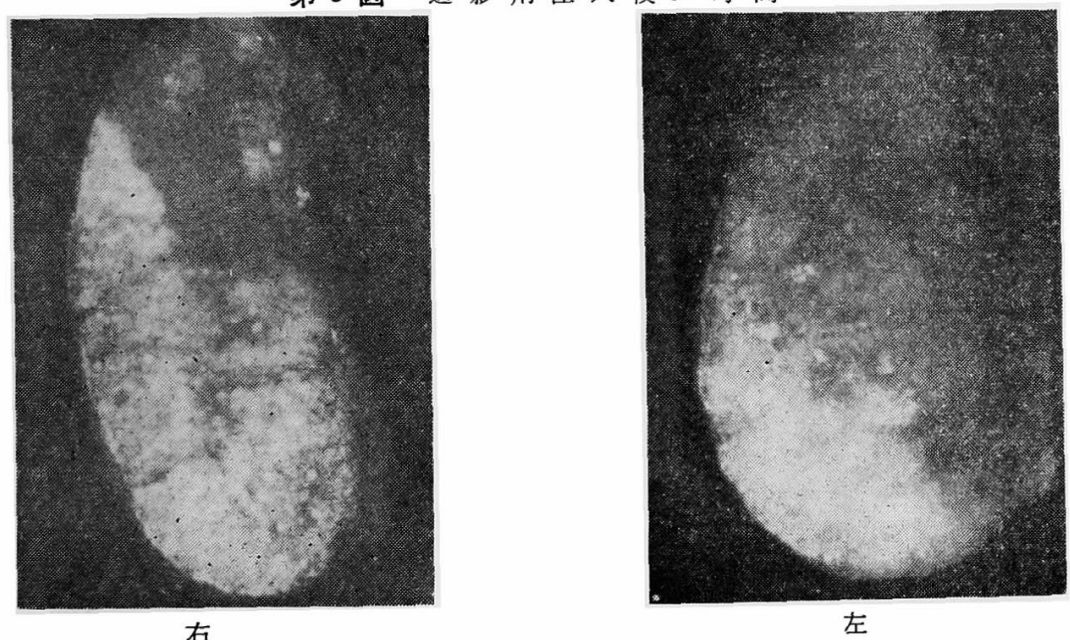

左

第 $\mathbf{1 0}$ 図造影剤注入後 20 日
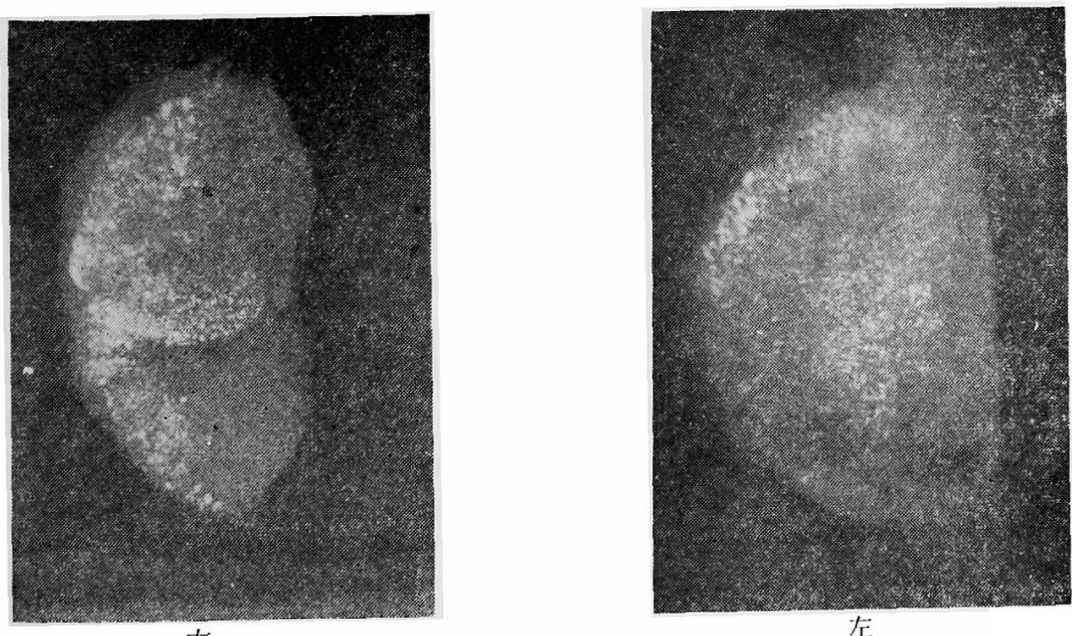
第 11 図造影剂泩入後 2 力月
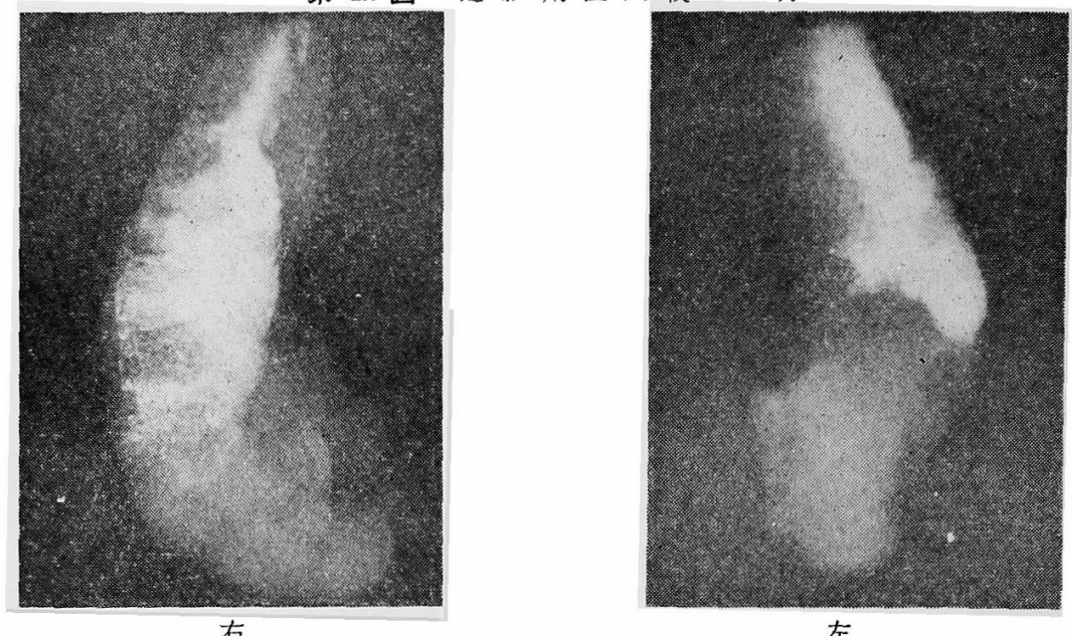

左

第 12 図造影剤泩入後 4 力月

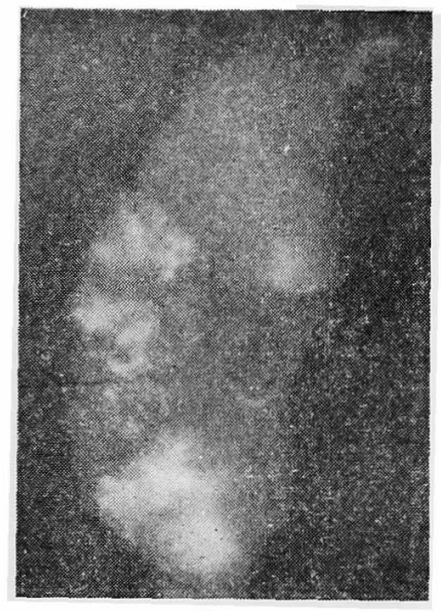

右

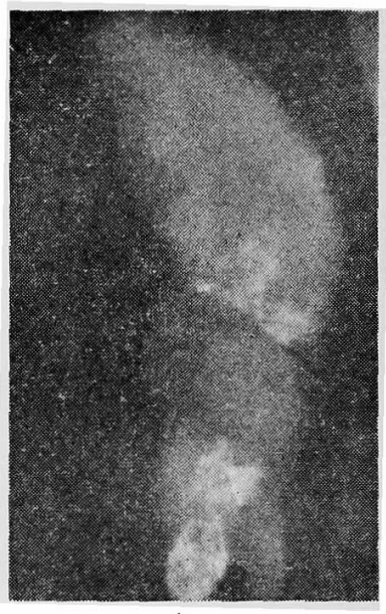

左

第 13 図造影剂注入後6力月
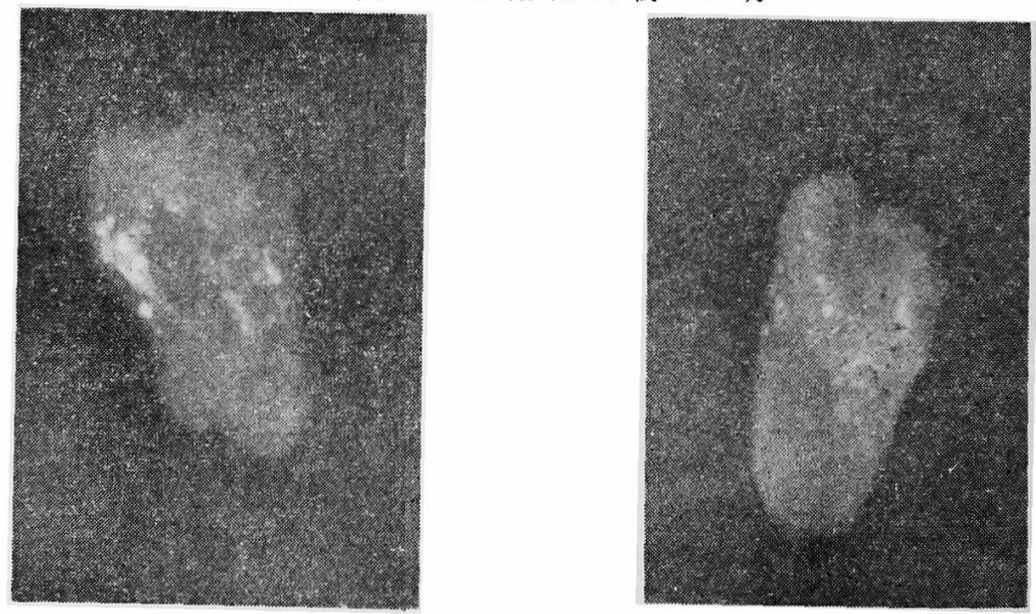

有

不 


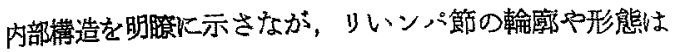
未だ判讜可能である.（第 5 図）

造影胱注入後3カ月のレ線像ではリンパ節内部で造影 成斿がり吸収されているのが目立らリンパ節像は数筒 の大をな状影欠損を呈する。しかしながら未だり ソハ節の輸廓および数の変化はみられない。

造影用注入後 4 カ月では造影剂はりンク節内に島状に

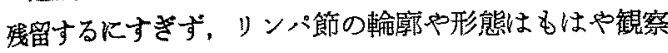
不能で両側深筫部リンパ節の存在が明らが記認められる 程度である。(第6図)

造影剂注入後 5 力月のレ線像は造影剂の断片的陰影を のこすのみでリンハ節の数を明確に観察できない.

造影剂注入後6 カ月のレ線像仕造影剒の散在性点状残 留像安示すのみであり，リンパ節の形態的観察は全く不 可能である。(第 7 図)

C 摘出リンパ節内造影削分布のレ線学的变化 摘出りンパ節に前章の実駼方法に抋いて述べた如く， 顿線に近い条体で拨大撮影を行うとリンハ節は造影剂の 存在しない部分は淡く描出され造影用の存在する部分は 明蹽に描出される.かくて得られたレ線像より，リンパ 節内造影剂の分布状熊を観察する事が可能である。

造影剂注入後 1 時間の摘出リンハ節拉大撮影像では, 造影用はりンパ節の紐絧構造を呈する事はなく全体にビ マン性の影像を形成する（第8図)

造影剂注入後 24 時間の抎大撮影像では均等な細網構 造を是しリンパ節の内部構造を忠实に表現している。 (第9図)

造影削注入後20日（第 10 図），1カ月のリンパ 節脑 大撮影像では，洞者を比較してみると特炕認もべき変化 はないが 2 力月 (第11 図)，3力月では浩影纱はりンパ 節の刀縁部に残存する傾向を示す。

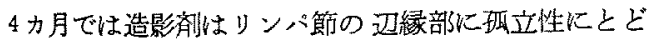
まり，島嗗状戏留像を示す（第 12 四）5力月では息舆 状残留像の陰影もうすれ，6力月（第13図)ではりンハ

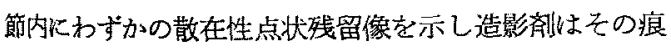
跡をとどめるにすぎい。

以上の如く，造影りンパ節は時間結過とともに節内造 影剂は眼収され消失していくだめりンパ節レ線像は次第 にうすれ旦つ，くずれて行くが各時期におけるリンパ節 像の造影程度を数值的に表見するために前章で述べた方 法により節内造影剂分布度を算比した。

節内造影剂分布度の時間的变化は第 14 図の加くであ る.すなわち，左深项部りンパ節の造影绡分布度は右の

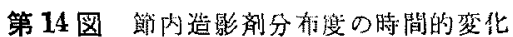

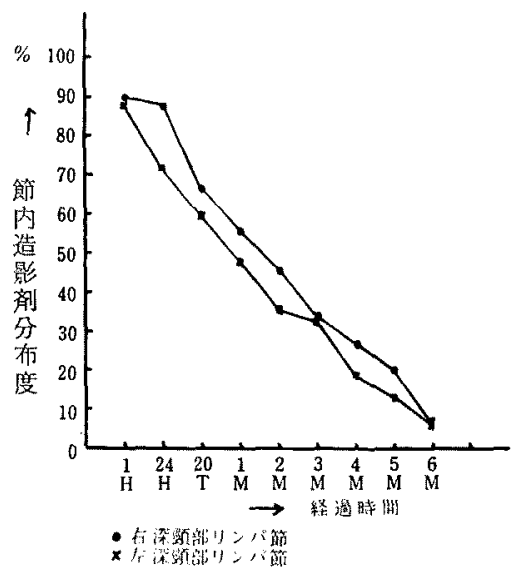

それよりる造影凧注入部位から遠隔にあるために各時期

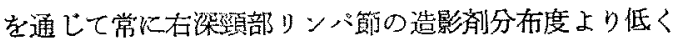
時間の経過にともなら造影剂分有度の減少は注入後 20 日までは急速に認められ，1 力月を過ぎると造影削注入 後の縃過時間に伴つて緩徐減少する.

\section{第 4 章 総括ならびに考按}

Kinmonth つらは下肢のリンパ管より造影剂を注入し 晹骨拉よび後腹膜腔のリソパ系造影炕成功しこれを臨床 的応用の段階汇さで進展せしめた。このリンパ系造影法 を頭頸部りンパ系に鹈入好九とする試みはU.P. Fisch4) らにより行われている。しかしながら未だその記載内容 は極めて簡略であり詳述されて扮らない，私は頭頱部り ンパ系造影法の基碟的事項を検討するにさきだら動物帮 験として正常犬頸部りンパ系造影法を行いそのリンパ系

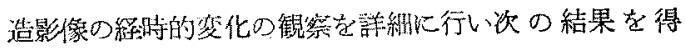
た.

犬の頸部リン八係は人のそれとはかなり異り，リンパ 節の数は少く旦つ，大型でその構成が極めて単純である ためレ線学的観察が容易である。多なわら，顎下部りン ハ節群より派生するリンハ管は同側の深頸部りンベ節に 到り，深頸部リンパ節の輸出管は一つは頸部リンバ総管

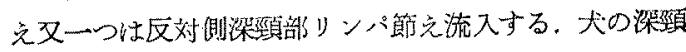
部りンバ節は人のそれとは異なり第】〜第【頸惟の高ざ に拇指頭大のすのがただ 1 筒存在するにとどする。

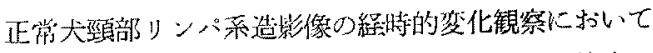
は造影剂注入後6カ月でも，な拉造影剂はンリパ筑队で 现立性飞点状陰影としてその残留像を認め得るが、リン パ節としての形態を確認できるのは，造影剂注入後 2 
カ月までである、リンパ管像は造影郕注入後 1 時間でも 認められるが 2 时間のレ線像で函めて広籁团にわたり明 瞭に認められ，24时間のレ線像ではりンパ管像は全く

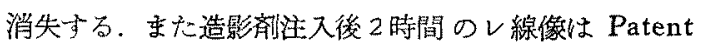
blue V Kよつて確認される正常犬頸部リンパ系の解剖 学的構成を極めて忠実脿表現している.

リンパ節像は造影斉拄入後 24 時間のものがその内部 構造観察のためには最子適当で，いかゆる均等細網構造 の典型的なる像を示す．均等細網構造は大体造影剂注入 後20日頃まで保た礼そ扎以後は濑次りンパ節内に批け

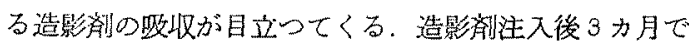
はリンハ節に斑紋状陰影欠損が多くみられ，6力月では 造影刘はりンパ節内で痕跡的に残存して点状残留像を認 めるにすぎない。

頸部リンパ系レ線像でその観察目的に上り最る適当な 撮影時陸は和のつがら限定されててくる。すなわち，正常 犬頸部りンパ系造影法においてリンパ管観察の目的には 造影郕注入後 2 時間のレ線像が最もよく、リンハ節観察 の目的には造影剂注入後 24 侍問のレ線像が最も適当で あると言える。

执大撮影を用いて摘出りンハ節内造影剂の分布を経時 的に観察してみると各時期によつてその分布状態にかな りの相違を認める。造影济注入後1時間のものでは造影 㨈は忹とんぞリンハ節の横断面全域にわたつてビマン性 に分布している。これは同一時期に和ける生犬のリンパ 節レ線像の造影状態と一致する，造影成注入後 24 時間 の㹡大樶影像ではリンパ節の内部棈造は鮮明に描出され て均等細絧構造を是しているがこれは造影剂がリンパ洞 よりリンパ節の奏質，すなわっち二次小節に浸入し、ここ に均等に分布しているために得られる影像と考えられ

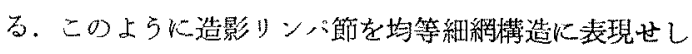
める造影滆の分有状態はかなり長期に加たつて継続し 20 日から1カ月まで羿められる、しかしながら，造影剂

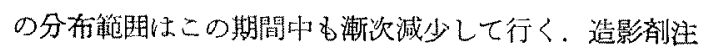
入後 2 カ月, 3 カ月となると造影刘はリンパ節の辺縁部 に残存する傾向を示すが，リンハ節門と思われる而側 に造影剂の分布は認めることが少く，凸面側に多く分布 する偭问が強いすなから，節内に一旦貯留された造影洞 は輸出管の近くに分布しているものから消失していくる のと思动れる.4カ月後では，それまで䬦内で連続的で
あつた造影剤の分布状態は島崄状となり孤立性となる。 すなわち，生犬のリンパ節レ線像の輪廓や形態力観察不 可能となるゆえ儿である。以後 5 力月，6力月と絟過す

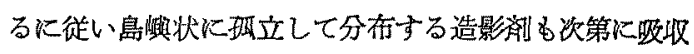
され遂には点状に残留像をのこすだけとなる。

抬大撮影によつて得られた摘出ンンパ節内造影冏分布 度を観察すると各時期を通して注入部位加ら遠隔儿存在 するリンパ節が注入部位の近傍にあるリンパ節よりる常 に造影剂分存度は低い，この事実は前述の如く，同一リ ンパ節に括いても，輸入管近辺よりも輸毕管近辺の方が 造影剂の消失が早いと言万事実上一致する。すなかち， 正常犬頸部リンパ系造影法に批、て造影像の消失は常に 中枢側からはじまると言う一定の法則が成立する。節内 造影楅分布度は造影剂注入後20日までに急速に減少し

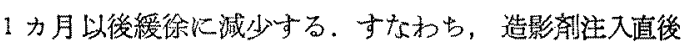
より20日までは造影削の機㖑的圧入により巨大に脑張 したリンパ洞が比較的短期间に縮少するので造影刘は急 速に減少するものと考克られる。1力以後の節内造影 剂は主としてりンパ節拜質内すなわち主として二次小節 に分布して扣り去のために造影骫の減少は極めて緩徐に 行われるるのと考光られる。

\section{第 5 章 結 論}

正常犬顓部りンメ゙系造影法につき，そのレ線像に括け る絽時的变化と，造影リンパ節の摘出標本における造影

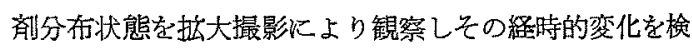
索し次の如き結果を得た。

1）リンパ管は造影剂注入後 2 時間で撮影されたもの が極めて広範囲にわたり最も明瞭渵出される。24時 間後にはリンパ管像は完全に消失する.

2）リンパ節は造影剂注入後 24 時間で撮影されたも のがリンパ節の内部構造を最も忠実に表現しレ線学的に 典型的な均等細網構造を描出する.

3）正常犬頸部りンパ系造影法に批いて造影像の消裉 ないし消失はリンパ采の中枢側からはじまる。

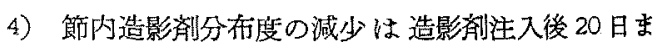
では極めて急速に行われ1力月以後ては緩徐に行われ る. 前者は主としてリンバ洞内の造影剂の消失の時期で あり後者は主として二次小節内の造影剂の消失の時期で ある。 


\section{第 2 篇 犬頸部造影リンパ節の病理組織学的観察（摘出リンパ節）}

\section{第1章 緒論}

造影リンパ節内における造影凨の分布を長期にわたつ て観察した報告は見当たらない。

リンパ節は胃，腸管および胆のう，血管などと翼なり 実質造器であり、リンパ系造影法を行うことにより奏質 蔵器内に造影剂を通過させるわけである，従つてリンパ 節炎、リポグラヌローマ, 油性塞栓症などを誘発する危 険子考点られる. リンパ系造影法施行後, 造影威は少く とも6カ月以上リンパ節内に残存寸ることは第 1 篇の奜 験によりすでに明かにしたところであるが，このような リンパ節内における造影斉の長期残存がリンパ節組織に どのような影響を拉よばすか現在のところ判然としてい、 ない.

私は犬頸部造影リンパ節の絼織内における造影威の分 布消長ならびにそれに伴らリンパ節組織の反応の経特的 変化を病理組織学的に観察する目的で次の如き実験を行 つた.

\section{第 2 章 実験動物ならびに実験方法}

健常成犬（体重 6〜10kg）を用いる. 使用頭数は 24 頭である.

第 1 篇，第 2 章に述べた方法に準じて犬頸部リンパ系 造影法を行つて 1 時間，24時間，20日，1力月，2力 月， 3 力月， 4 力月， 5 力月， 6 力月， 9 力月拈よび 12 カ月後の各時期に左深頸部リンパ節を摘出しリンパ節組 織内に打ける造影郕分布状態の経時的変化を観察するた めズダン II染色を，リンパ節組織内のリンパ系細胞構成 の経特的変化を観察するため $\mathrm{HE}$ 染色を, リンパ節組 織内の細絧組織の経持的变化を観察するため鍍銀染色 を、リンパ節組織内の膠原線維化の経時的变化を観察す るためヴアン・ギーソン染色を行ら．

\section{第3 章 実 験 成 績}

A リンパ節䋎織内に拈ける造影剂分布状態の経时 的変化

造影リンパ節内に存在する油性造影威を顕微鏡下で観 察するため脂質の唡出法として最も広く用いられるズダ ン【染色を応用した。

造影剂注入後 1 時間のリンパ節組織内に拝いては, 造 影凧はリンパ洞全体に $100 \sim 120 \mu$ の油滴として認めら れる. (第 15 図) リンパ節内の二次小節や骮索すなわ ち、リンパ節実質内には造影剂は認められない.

造影成注入後 24 時間のリンパ節組織像は造影剤が更
第 15 図造影剂注入後 1 時間 Sudan II 染色 $\times 100$

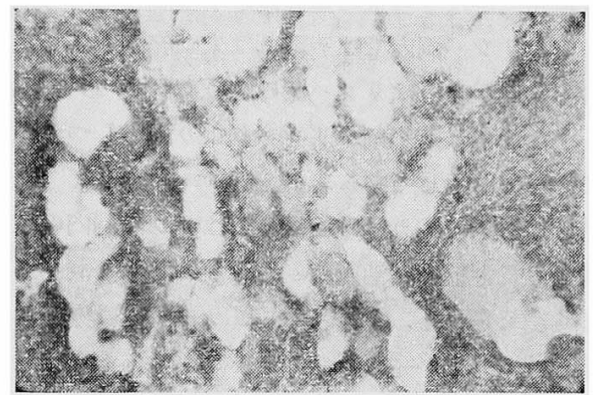

第 16 図造影㓮注:入後 24 時間 Sudan 四染色 $\times 400$

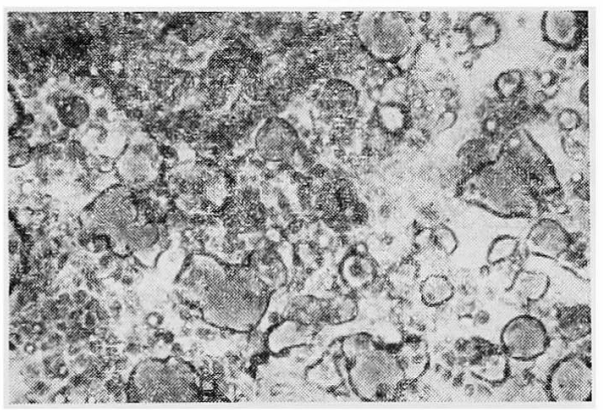

第 17 図造影剂注入後 20 日 Sudan II 染色 $\times 100$

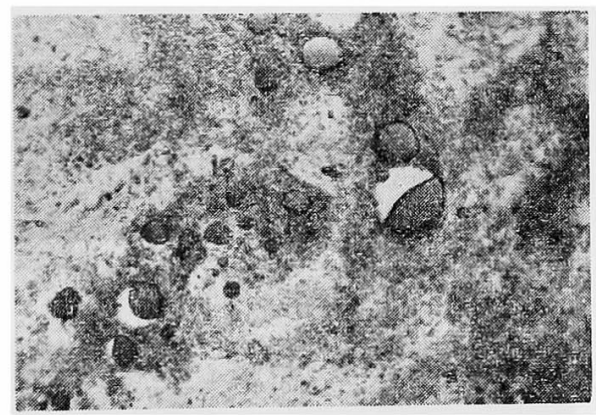

に小さな 15〜20 の の油滴となつてリンパ洞からリンパ 節組織の実質内に侵入し散在している. 又かなり多量の 造影剤がリンパ節内に含まれているためいくつかの油滴 が融合して造影郕の塊が斑皎状に存在する，(第16図） 造影剂注入後20日の組織像に拈いては, リンパ洞はか なり著明に縮小しているが，造影威は充満し，リンパ節 実質内ではかなり大きな油滴も存在するが (第 17 図). 
リンパ洞より実質内に移行した造影剂は小油滴となつて 存在し一部は巨大細胞に領食された形で分布している.

造影剂注入後 1 力月の組織像ではりンパ節実質内に未 だ広範囲にかなり多量の造影剂が小油滴となつて散在し ている.リンパ洞内では造影剂け未だ充满して存在する ものもあるが多くはりンパ洞の腔壁に附着して存在す る. すなわち，造影唷がリンパ洞より流出しつつある時 期である事を示している.

造影玟注入後 2 カ月の組織像ではリンパ洞内の造影刘 は消失して, 拡大し油滴のみられないリンパ洞が目立つ て多く認められる.すなわら、リンパ洞内に充満してい た造影峢の流出が完了しつつある時期である事を示して いる.リンパ節实質内の造影剂はすでに大型の油滴とし て認められる隶は少く，多くは小油滴としてあるいは巨 大細胞に舍食された形として認められる (符 18 図)

造影剂注入後 3 力月の組織像ではリンパ節の組織には むはや造影剂は均等に認められず，かなり広範囲の部分 に全く油滴が存在しない部位もある.油滴はリンパ節の 辺縁部潗合する傾向を示す.

造影剂注入後 4 カ月の組織像では造影剤の油滴の分布

第 18 図造影剂注入後 2 力月

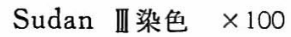

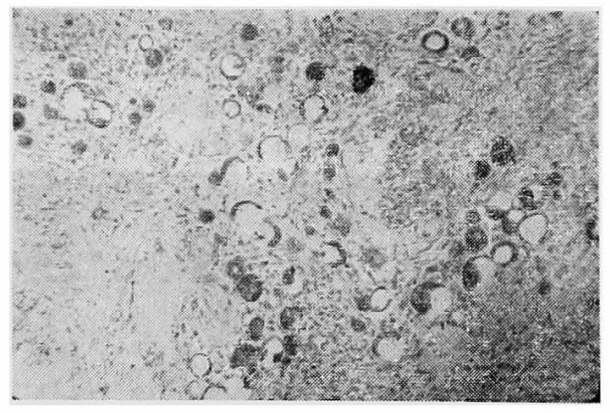

第 19 図造影剂注入後 4 力月 Sudan 【染色 $\times 100$

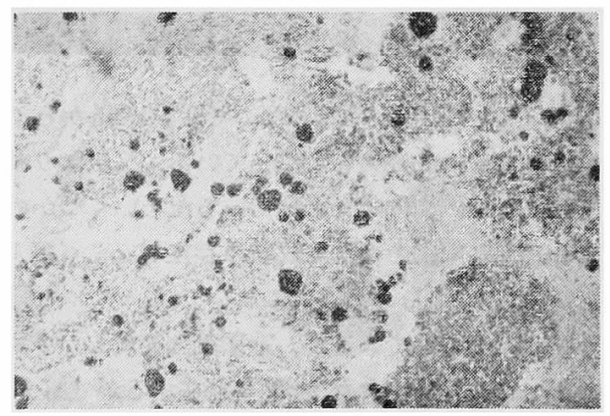

範囲はかなり減少して，造影版分布領域ではリンパ節組 織の荒廃が認められる.（第 19 図)

造影剂注入後 5 カ月ではりンパ節組織内の造影剈分布 領域の油滴の数は著明に減少し，リンハ節をとりまく結 締織の增殖が著眀となる。

造影剂注入後 6 カ月の組織像では造影剤を良食した巨 大細胞の集らくがところどころにみられ，このような部

第 20 図造影剤注入後 6 力月 Sudan 饪染色 $\times 100$

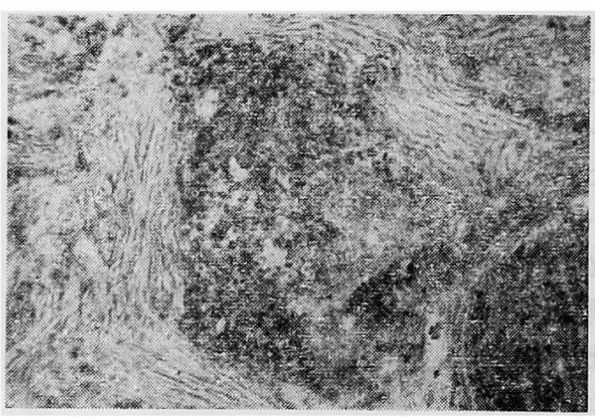

第 21 図造影剤注入後 12 力月 Sudan 染色 $\times 100$

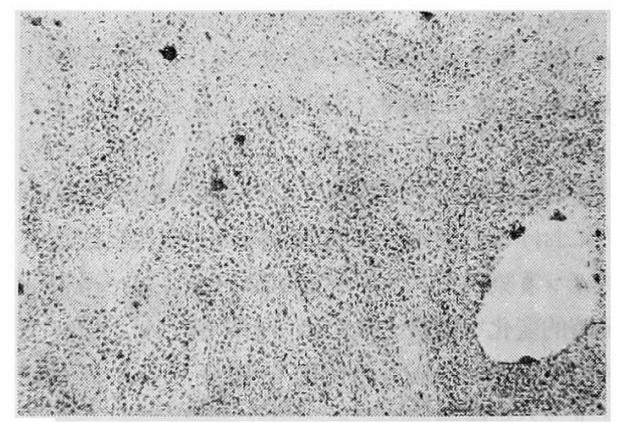

第 22 図造影剤注入後 1 時間 $\mathrm{HE}$ 染色 $\times 100$

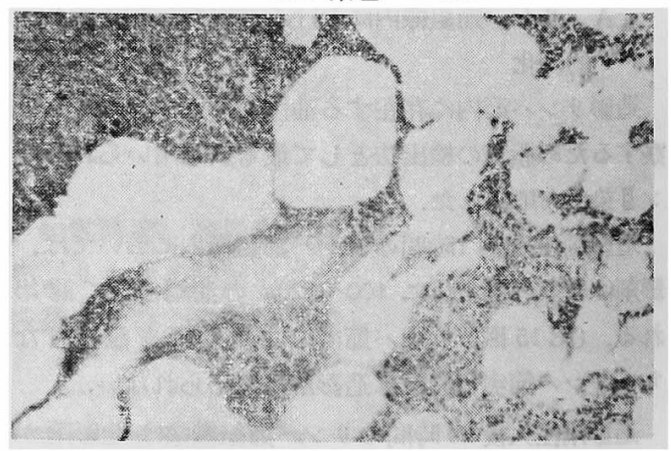


分ではリンパ節組織の荒成が特に著明である（第 20

図)

造影威注入後 9 力ではな打極小部分では造影成の小 油滴の集らくが認められるがリンパ節組織の荒廃は著明 ではい。

造影剂注入後 12 カ月ではリンパ節実質内に 造影唷の 小油滴の集らくは全く認められず，わずかに2〜3コの 油滴が散在する部分がまれにみられる程度である。リン 䒔洞では造影剂はその腔壁に点状に附着していることも あるが大部分のリンパ洞はからである。（第 21 図）

B リンパ節組織内のリンパ系細胞構成の経時的变 化

犬钼部リンパ系造影法施行後の各時期にぶける左頸部 リンパ節を摘出して HE 染色を注どこしその 組織学的 変化，特にリンパ系細胞構成を絽特的に観察する。

造影斉注入後 1 時間の䋎織像はリンパ洞，特に辺縁洞 の著明な㹡張をきたし，リンパ節実質のリンパ球の密集 した王迫像が認められる。（第 22 図）

造影剂注入後 24 時間の組織像に5いては注入後 1 時 間でみられたようなリンパ洞の巨大な抁張像はすでに認 められないが，リンハ洞は依然として中等度の抬張を示 している.

造影剂注入後 10 日の組織像はリンパ洞，特に辺緣洞 は搪張し好中球, 赤血球の出現の外，この部の細網細胞 は厙大，增生し遊離，円形化して洞カタルの状態を示 ナ、リンパ洞内には鼠物巨細胞の出現を諗める。（第 23 䀦)

造影剂注入後 20 日の組織像では異物区応が堷明で異 物巨細胞が多数認められ，リン：球系細脚は減少してい る.

第 23 図造影阁注入後 10 日 $\mathrm{HE}$ 染色 $\times 100$

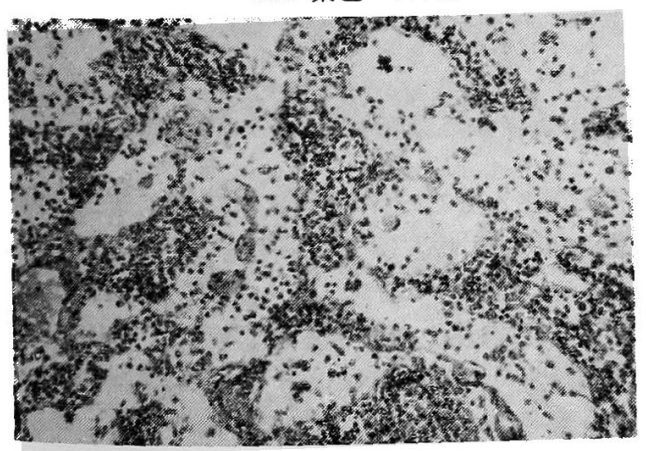

造影省注入後 1 力月の組織像ではリンパ球形細胞は更 に減少し，細網細胞が增殖してリンパ洞には膠原線維化 が扰こりはじめている（第 24 図)

造影削注入後 2 力月括よび 3 力月になるに従つてリン 球系細胞の減少と噖原線稚の增殖は平行して進行す 万.

第 24 図造影郕清入後 1 力月 $\mathrm{HE}$ 染色 $\times 100$

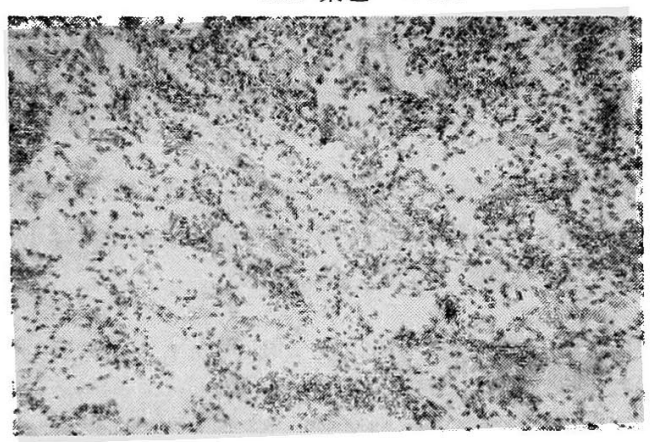

第25図造影㓮注入後 4 力川 $\mathrm{HE}$ 染色 $\times 100$

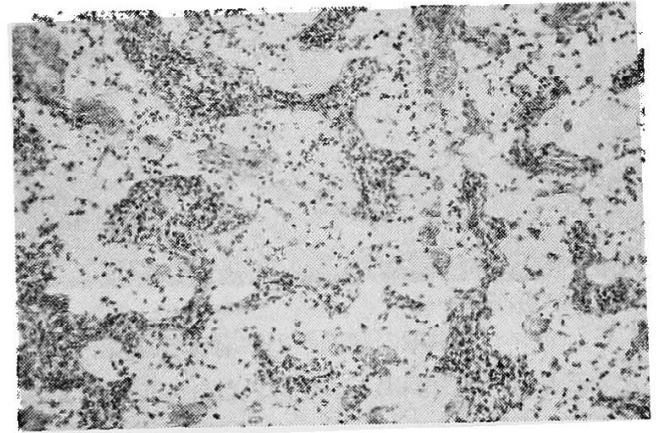

第 26 図造影㘊注入後 6 力月 $\mathrm{HE}$ 染色 $\times 100$

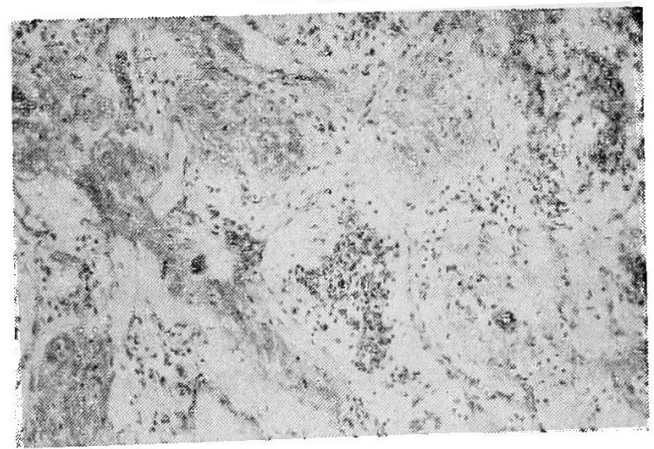


4 カ月の組織像はいわゆるリポグラヌローマの所見が 認められる。（第 25 図）

造影郕注入後 5 カ月ではリンパ節組織は部分的には者 しい細胞浸潤をともなつた膠原線維の增殖が扢こり些質 細胞は減少して線維性硬化を起してくる.

造影浏注入後 6 力月では実質細胞の減少之線維性硬化 の程度は局部的に最高に達するが，リンパ節紹織全体か らみれぱリンパ節本来の構造さ失われていない（第 26 図)

造影剂注入後 9 カ月の組織では線維性硬化は減少しり ンパ球系細胞は墙殖してリンパ節組織の構造は正常化の 傾向を示す.

造影剑注入後 12 カ月の組織像はリンパ 球形細胞構成 の正常化とともに二次小節やリンパ洞の形態もほぼ正常 リンパ節の組織像を示す。（第 27 図）

第 27 図造影剂注入後 12 力月 $\mathrm{HE}$ 染色 $\times 100$

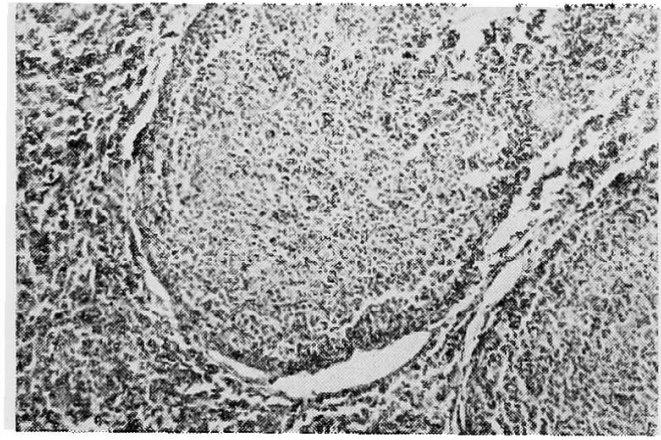

Cリンパ節組織の組網系細胞搆成の結洔的変化 犬頸部リンパ節を摘出し鍍金染色を行つて細網紹織の 絴時的变化を観察する。

造影削注入後 1 恃間の組織像は造影刘の機械的生入の ためにリンバ洞は拚張されリンパ節失質に絕織の破壊像 がみられるが，紐網組織ではその細網線維が寸断されわ なり高度に破壊されている.（第 28 図)

造影威注入後 24 時間の組織像では細網組織の墙殖が みられ，すでに細網細胞より生じた大食細胞を羿める. (第 29 図)

造影削注入後 20 日の緼織像では細網紌胞の增殖と大 食細胞の增加が目立つてくるが細網線維が連絡して形成 する網目中のリンパ球は極めて柾である（第 30 図）

造影郕注入後 1 力月の緝織像では膠原線維化が認めら れる。
第 28 图造影剤注入後 1 時間 銥銀染色 $\times 400$

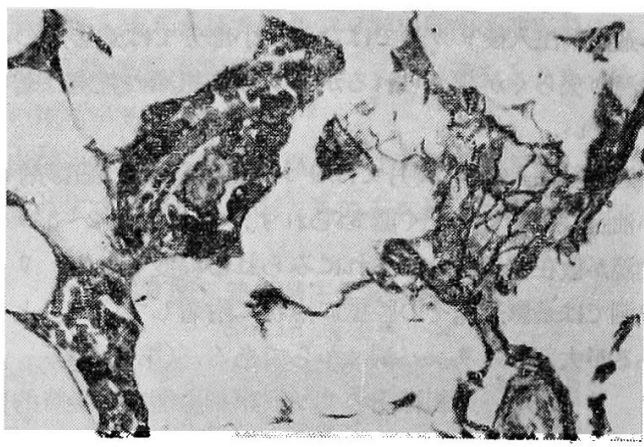

第 29 图造易剂注入後 24 時間 毁銀染色 $\times 400$

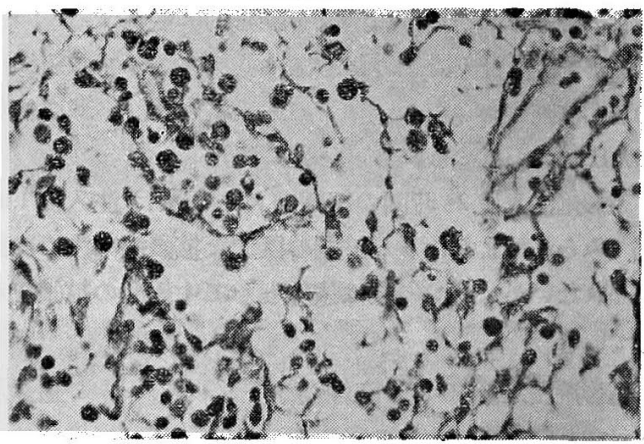

第 30 図造影郕注入後 20 日 錙銀染色 $\times 400$

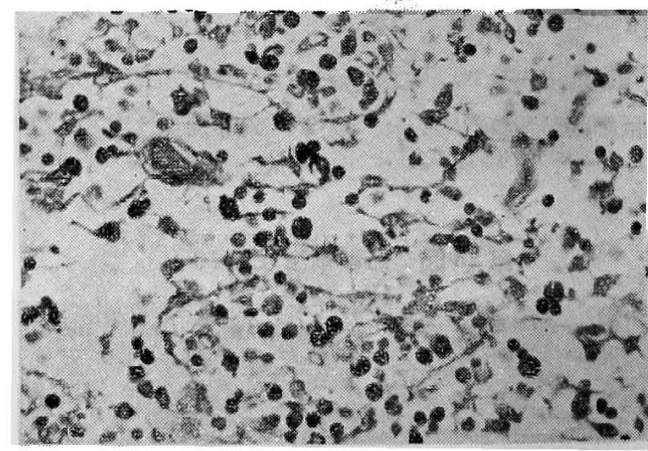

造影剤注入後 2 力月の絙織像では細網組織の中に格子 線維が㨋明に入り込んでいる所見を認める.（第 31 図）

3 カ月，4 力月， 5 力月 (第 32 図)，6 力月になるに従 つてリンパ節組織の膠原線維は增殖するが細網組織と， 細網線維が形成する網目中のリンパ球の增加は確実に認 められる。 
造影郕注入後 9 カ月では膠原線維や格子線濰はあまり 目立たなくなり，その網日中にリンパ球を充満させた細 䊑鶭繥が認められリンパ節本来の構造に近い組織像とな る. (第 33 図)

造影斉注入後 12 カ月ではその組䌬像は無操作のリン 、節とは活とんど区別がつかない（第 34 図）

第 31 図造影剂注入後 2 力月 鍍銀染色 $\times 400$

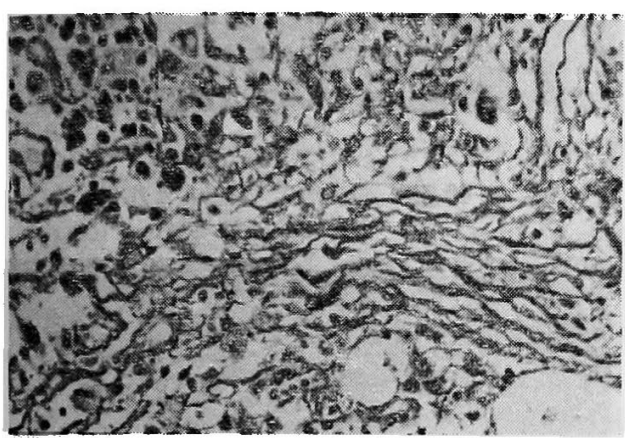

第 32 図造影率沬入後 5 力月 錙銀染色 $\times 400$

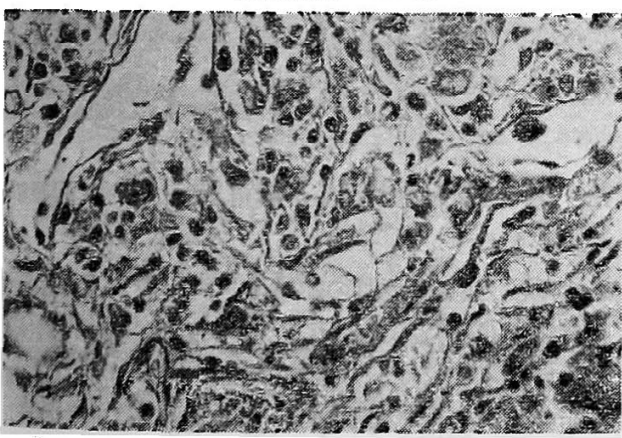

第33图造影剂注入後 9 力月 鋌銀染色 $\times 400$

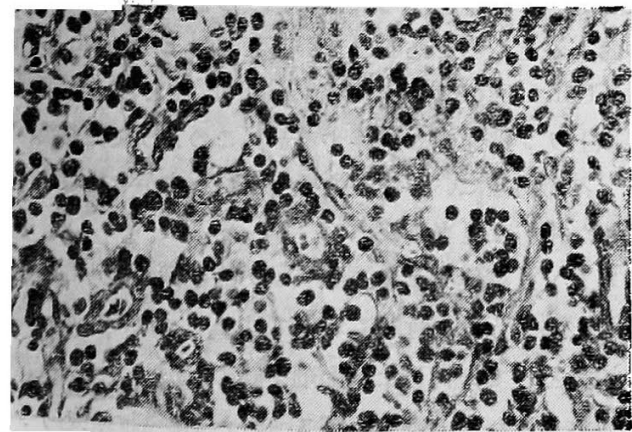

第 31 図造影剤注入後 12 力月

鍍銀染色 $\times 400$

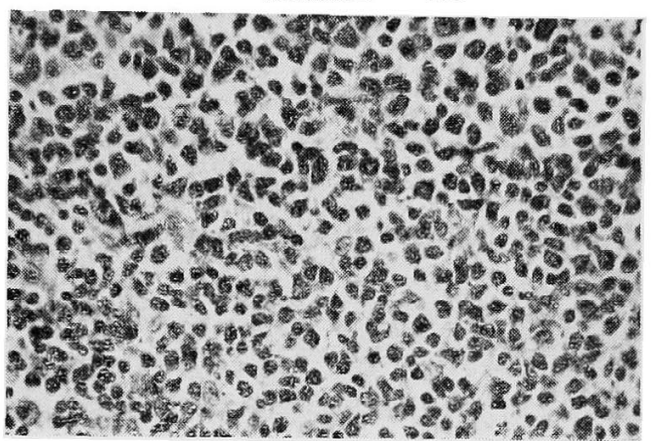

D リンパ節組織内の線維化の綩時的変化

造影剂の注入されたリンパ節は造影剂が異物となつて かなり長期にわたつて刺践をらけるため非特異性単純性 资症を掞こしてくる. そのためリンパ節組織に膠原線維 化がおこるが，これらの変化を経特的に追求するためり ンパ系造影施行後の各時期の摘出リンパ節にヴフン・ギ ーソン染色を行つた.

造影阂注入後 1 時間および 24 時間の組織像では未だ 膠原線維の增殖の兆は認められない（第 35 図）

造影昘注入後 20 日の組織像ではリンパ球の減少を 認め大食細肘の出現と細網組織が目立ちはじめる時期て あるが同時にリン゚゚洞の膠原線維化がはじまる。

造影能注入後 1 力月の組織像ではリンパ節実質内にも 細胞間隚に膠原線維の侵入が認められる.（第36 図）

造影昘注入後 2 力月の組織像ではリンパ節実質内に侵 入した膠原線維の増殖がおこり一部では結締織化の傾向 を示す.（第37 図）

3 カ月, 4 力月, 5 カ月となるに従つて膠原線維はり

第 35 図造影刻注入後 1 時間 Van Gieson 染色 $\times 100$

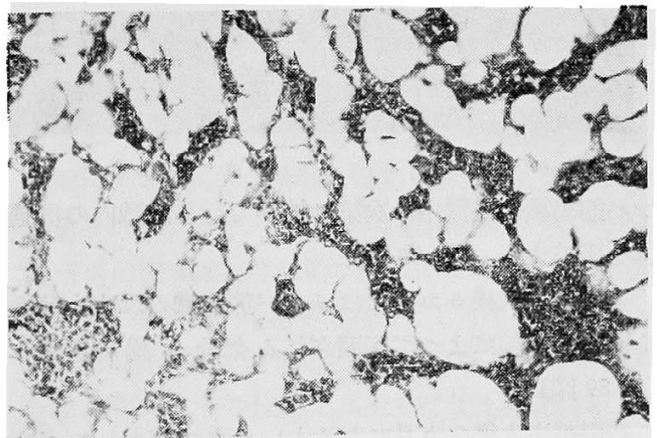


第 36 図造影剂注入後 1 力月

Van Gieson 染色 $\times 100$

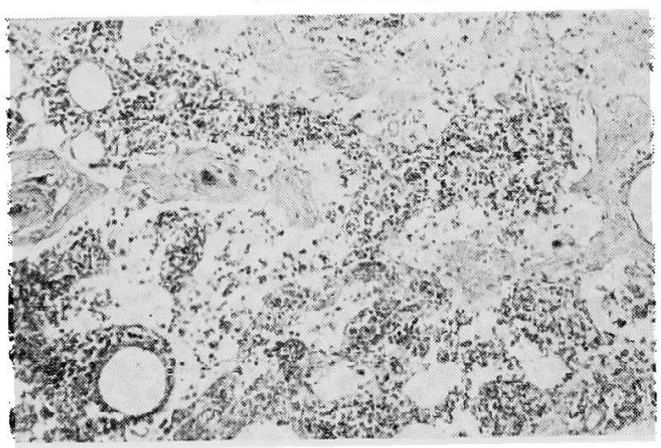

第 37 図造影刻注入後 2 力月

Van Gieson 染色 $\times 100$

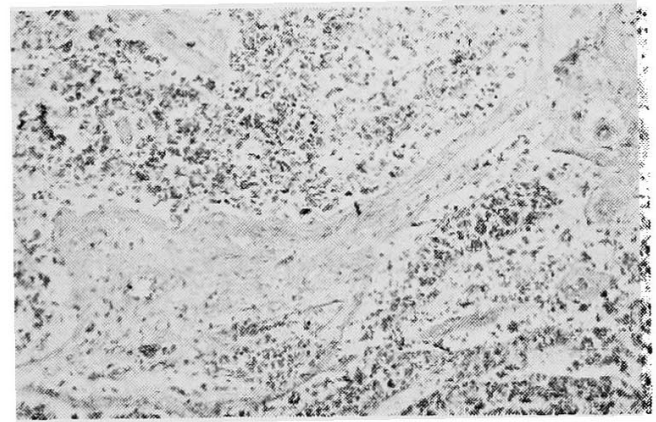

第 38 図造影殽注入後 5 力月

Van Gieson 染色 $\times 100$

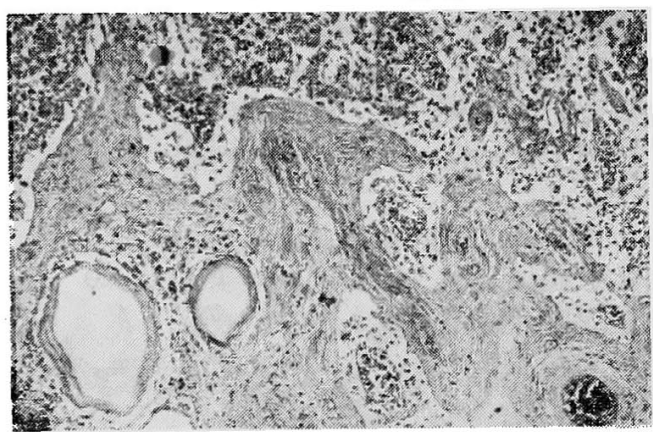

ンパ節組織の実質内に次第に扰つて行き組織内の細胞構 成を王迫する.（第 38 図）

造影剤注入後 6 力月ではリンパ節組織の二次小節は完 全に廖原線維によつて包囲される 部分 方認められる.

(第 39 図)

造影威注入後 9 カになるといままで減少しつづけて
第 39 图造影剂注入後6カ月

Van Gieson 染色 $\times 100$

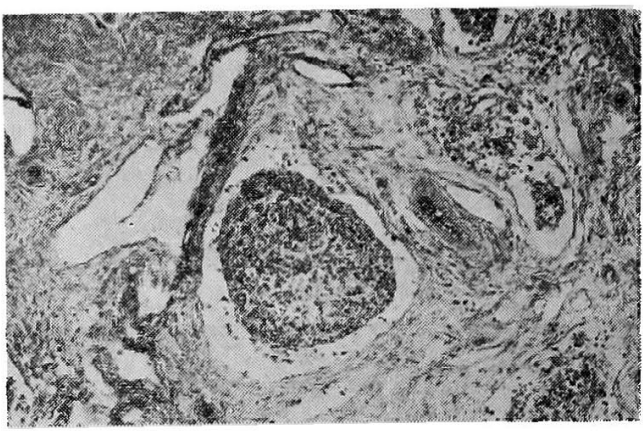

第 40 图造影剂注入後 12 力月

Van Gieson 染色 $\times 100$

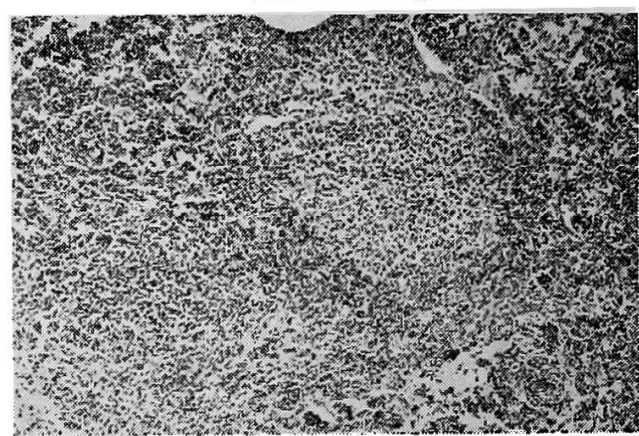

きたりンパ球系細胞の堌殖が活発となり，逆に愿線維 の減少をきたす。

造影剤注入後 12 カ月の組織像ではリンパ 組織実質内 に膠原線維化は認められずリンパ系組織, 細網系組織, リンパ二次小節，リンパ洞など全てリンパ節の構造は正 常の組織像に恢復している. (第 40 図)

第 4 章 総括ならびに考按

造影削注入後のリンパ節に巨大細胞の出現による異物 反応が扣こることは Jackson 5) らをはじめ多くの学者 の認めるところである. しかしながら Ethiodol, Lipiodol Ultra-Fluide 和よび popiodol などの造影郕は1 年以上リン,節内に残存するが，このような長期䂝存が リンパ節組織にいかなる結果をもたらすかを経時的に観 察した報告は見当らない。

スダン染色による造影リンパ節組織の経時的観察で

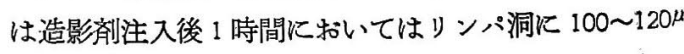
の油滴として充满した造影成を認めるがリンパ節実質に は認められない，洞内に圧入された造影剤のためリンパ 
洞が高度に拉張して実筫は圧排せられている、それ故， この時期のリンパ節レ線像は造影剂のリンパ洞内への機 珹的夼满により形成されるのである。

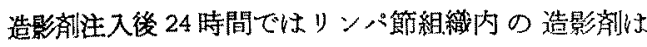
リンパ洞に充满している一方，実筫内にも 15〜20.4の 小油商となつてビマン性に無数に分布している：この时 期のリンパ節レ線像が均等紐絧棈造を形成するのはリン

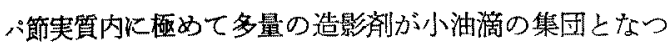
て含有されるためと考えられる。

造影刘注入後 20 日の組織像ではりンバ洞の著明な縮

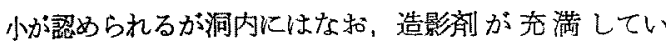
る、リンパ節実賀内に执いて造影刘は巨大細胞に食食さ れはじめる。

摘出りンパ節拡大撮影による造影郕分布度曲線が注入 後!時間から20日までに急速に減衰するのはこの閂に 造影斉の機峨的充満で巨大に㹡張したリンパ洞が急游に 繀少するためと考えられる。

造影剂注入後 1 力月ではリンパ洞内の造影冏は流出し はしめ 2 カ月から 3 カ月の間に洞内の造影剂流出は完了

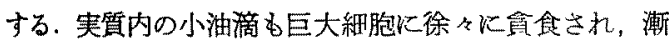
次リンパ節実賀内の小油滴の分布範用が縮少されてい く.摘出リンパ節の拉大撮影に上つてレ線学的に得られ た造影闵注入後 1 カ月から6力月までの節内造影剂分布

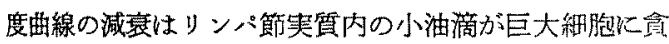
食されていく過程を示暗するすのと考完られる。

造影剂注入後 4 カ月より及られたリンパ節組織の荒溌 屿大紐胞の增加と之もに6カ月に最も著名となり9力 月，12カ月になるに従つてりンパ節内の小油滴と造影 削を真食した巨大細胞の隇少に平行して荒廃した部分も 消失していく.

HE 染色炕上り， yン八球系細胞の経特的変化を観

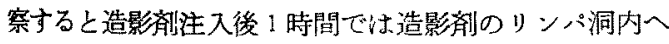
の機找的王入で同は巨大な㹡張をきたし，そのためりン ハ節聿質の細胞構成は压迫されリンパ球は極めてつよく 密集した状態になる.10日後の絽織像は洞カタルの所 見を是し，20日後では異物反応が著明でリンパ球系細 胞の減少をきたしはしめる。それ以後6カ月迄はりンパ 球系は䋥胞の減少は漸次高度となり，それに平行して目 原線維化の範囲が㹡大する，6カ月をすぎるとりンパ節 組織の膠原線維化は縮少しリン八球系細胞の堌殖が扰こ ク9カ月を䌊て 12 カ月になるとリンパ節組織は本来の 構成に满復する。

鈘銀染色により各時期における造影りンバ節の細網縕
織の熊度を観察すると, 造影杪注入後 1 時間の組織像で 細網組織の棈造は造影頝のリンパ洞内えの機械的圧入の ためかなり高度な破壊像が認められる。すなわち、リン パ球系細胞上同様細網䒺細胞の区迫集ならびに細網線維 の断裂像を認める. 注入後 24 時間では細網組織より巨 大食細胞の発生が認められ，20日，1力月ではりンパ 球系細胞の減少に平行して細網組織の增殖と大食細胞の 堌加がみとめられ，この頃より，リンパ節実質に坬立性 または散在性に腾原線維や格子線維の出現が認められ る. 2 力月、 3 力月絽過せるものでは膠原線維や格子線 維の增殖，大食細胞の增加が更に進み，4力月，5力月 ではりンパ節組鐵内では島嚖状の線維化が認められる。 造影斉注入後 6 カ月になると更に線維化は進みメンバ節 組織内の一部では結締織がリンパ二次小節を包团してい 万所見が喼められる。文この時期のリンパ節実留に極め て多数の大食細胞艻集らく在形成して存在する。9力 では賿原線維や格子線維:の減少が扢こり細絧組織は細絧 線維の網目中にリンパ球系細胞方゙增加し大食細胞は減少 してンンパ節組織本来の構成に恢復する兆候が諰められ る. 注入後 12 力月ではリンパ球系細胞が細網線維の網

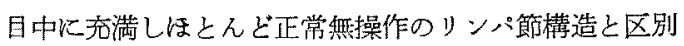
がつかないまで恢復している。

以上の如く細絧組織は，異物としての造影威のリンパ 節侵入に対してりンパ節組織の罢物区応に関与する。す

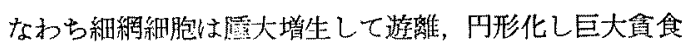
細胞となつてリンパ節笑質内の造影郕の小油滴を舍食す る。同時に細䋧組織は增殖し洞は图原線維化や格子線維 化が扰るリンパ節実質内の造影剠が漸次排淮されるに 従つて線維化の㖽向は消裉して正常りンパ節構造に恢復 する。

異物としての造影剂が持綕性に作用することにより，

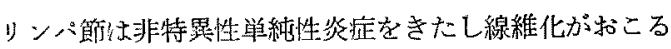
が，造影郕注入後の各時期の造影りンパ節にヴアン・ギ ーソン染色を施して猛持的に線維化の状態を観察する と，造影剂注入後 20 日ではリンパ洞の閦原線維化がは じる，それ以後，6力月までリンパ節組織内で線維化 恬進行するが高度の線維性硬化や非可逆的な碍子様变性 に陷ることはなく、, カ月では線維組織の減少を認め, 12 力月の組熾像では組縕つ線維化はほとんど認められ ないすなおち，造影剤け鼠物ししてリンパ節に作用し 軽度の紧純性炎症をきたし一旦はりンパ節組織に線維化 をきたすが，その程度け高度ではなく可逆性の変化の ためりンパ節絽織から造影剂が排淮されるに徒つて線維 
化は消䙉していく.

\section{第 5 章 結 論}

犬形部リンパ系造影法を行い，造影リンパ節の病理組 織学的变化を梌索して次の如き結果を得た。

1）造影感はリンパ節組織内で，はじめはリンハ洞内

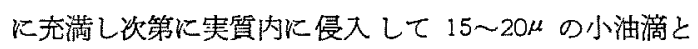
なつて残留する.小油滴は大食細胞によつて貫食され遂 にはリンパ節組織から消袏する。

2）リンパ節は暴物としての造影涧の持続性刺㦸のた め緩徐な非特異性単純性炎症をきたし，リンパ球系細胞 は漸次娍少するが，造影剂の小油滴が苓食されりンパ節 組織から消袏するに従つてりンパ球系細胞は增殖して本 来のリンパ節組織比恢復する。
3）造影リンパ節の細網組織は造影当初は造影剂の機 械的圧入により細網細胞の強度な王迫像と細網線維の断

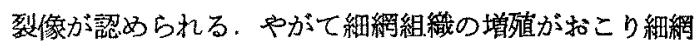
細胞は蹗大增生し遊離，円形化して巨大食細胞を形成 し，一方では細網線維は洞周辺部より愿原線維化を落起 する.膠原線維化の隇少に平行してリンパ球系細胞の增 加する時期になると大食細胞の消很がおっこり細網組織も 本来の構成にもどる.

4) 造影リンパ節組織の線維化は造影後20日より認 められ，6力月で最も著明であるが高度の線維性硬化や 硬子様変性怯認められない，その後は線維化は漸次消袏 し，造影後 12 力月で無操作正常リンパ節とはとんど変 らない組織像を示す。

第3 篇 正常犬頸部リンパ系造影法にとるな5 油性塞栓症の問題

\section{第 1 章 緒 論}

リンパ系造影飞ともなら油性塞柽症巷起の可能性の有 無は充分に検討を要する問題である.

この点下肢などの報告に牱いても，その可能性につい ての注意が述べられているが5)，特に頸部りンパ系造影 に拉いては造影剂注入リンパ管が静脈に合流するまでの 距離が短いため一層の留意を要する。

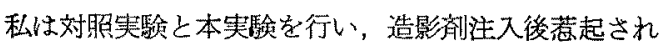
る症扷の絽過観察と胸腹部レ線撮影, 重要藏器すなわち 肺, 脾, 肝, 腎の病理組織学的変化の短察を行い, 実地 臨床応用にあたつていかにすれば危険をさけられるかを 検討しようと思う。

\section{第 2 章 実験動物ならびに実験方法}

健常成犬（体重 6 10kg）を用いる。使用頭数は対 照実験群括よび本実験群ともにそれぞれ 5 頭である.

实験はイソミタール腹腔内注入麻䣲の下に実施する。 すなわち体重 $1 \mathrm{~kg}$ につきインミタール 0.05gr あて注 入すると動物は 15〜20 分後完全作酔される。実験は イソミタール注射後 30 分以上絽過してから着手する。

対照実䜽は正常犬に打ける頸部リンパ系造影法に上も なら油性塞栓症の問題を検討するため，動物を固定台上 に背位に固定し実験的に造影冏による油性塞栓症を形成 する。すなわち，5頭の犬の右浅頸静脈に造影闵 popiodol $0.3 \mathrm{ml} / \mathrm{kg}$ 静脈注射して人工的に油性塞栓症 形成し，犬の一般状態の観察，胸腹部レ線像の観察，重 要臓器すなわち，肺脾，肝，腎の組織に HE 染色を
ほどこして病理紷織学的観察を行う.

本実験は 5 頭の健康成熟犬の頸部リンパ系造影法を施 行する。第 1 篇，第2 章の方法に淮じてこれを行い，造 影剂注入後 24 時間で屠殺して対照实験と同一事項につ いて観察を行い，両実験成績を比較检討した。

\section{第 3 章 実験成 精}

対照実駼例すなわち，造影剂の浅项静脈静注例では， 造影滆注入後，漸次，四吸が促迫し，対䀡実験例 5 例は すべて 24 時間以内に死亡する.

これに対して本実験すなわら，造影剂の顎下部リンパ 䬣注入例では 5 例とも 24 時間以内に死亡する事はない。

胸部レ線像においては，対㫟実験例では全て雨肺野と くに右肺野に著明な微粒子状，〈子状，あるいは網状陰 影像を認める. (第 41 図) 本実験例では 5 例中 1 例にの み右上肺野にわずかなビマン性陰影を認めたが，他の4 例は全く買常を認めない，(第 42 図)

腹部レ線像では対照実験例，本実験例とも異常を認め ない.

次に, 重要藏器すなわら, 肺, 脾, 肝, 腎の $\mathrm{HE}$ 染 色法に上る病理組織学的所見について述ぺる。

対照実験例では全例に打いて，肺は肺胞中隔が著明飞 肥厚し，らつ血がつよく肺胞粘膜の損倁がおこり，組緎 の㙘死が認められる。(第 43 図)

これと対して本実験例では全例に招いて肺の組䋘像化 特に異常所見を認めない（第 44 图)

脾蔵については対炤実験例では脾滤胞の中心が硝子様 

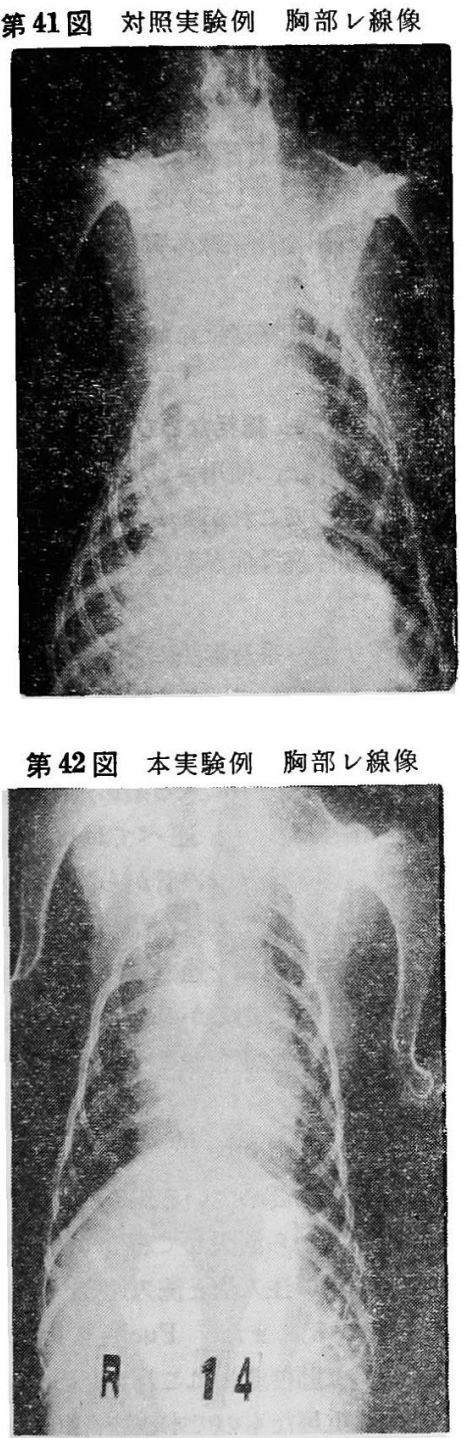

第 43 图対照実験例（肺 $\times 100 ）$

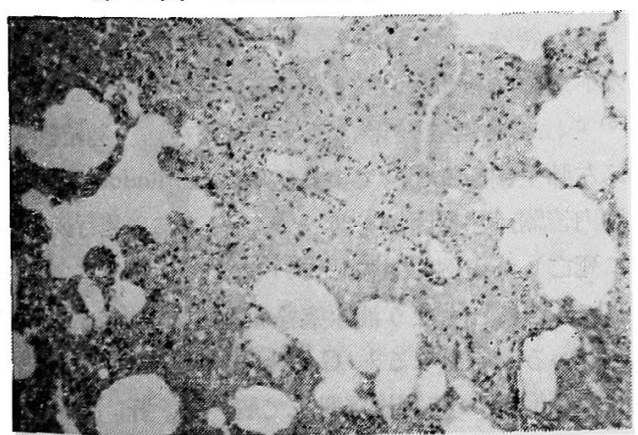

第 44 図 本実験例（肺 $\times 100 ）$

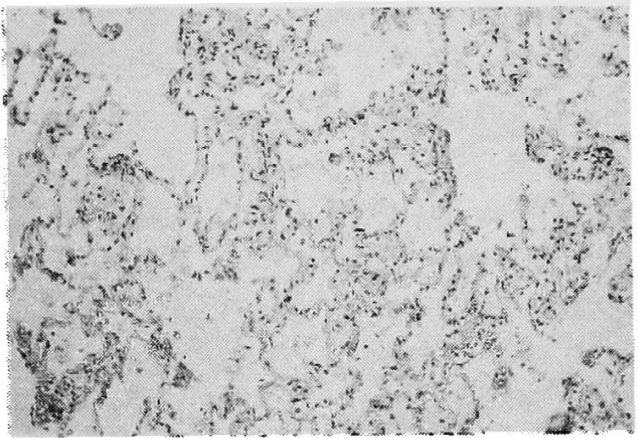

第 45 図対照寒駼例（脾 $\times 100 ）$

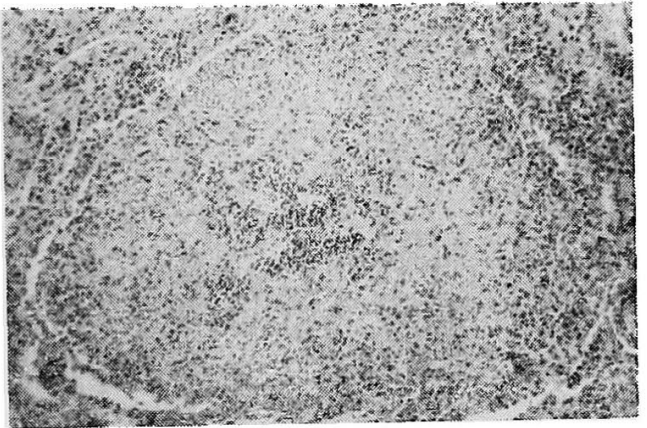

第 46 図 本実験例（脾 $\times 100 ）$

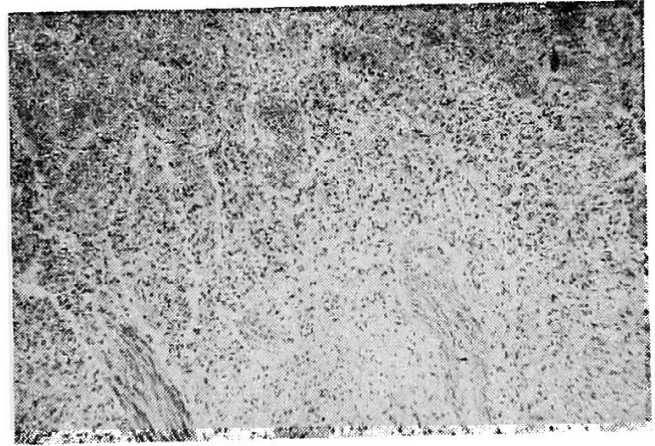

第 47 図 刘照害駼例（肝 $\times 100 ）$

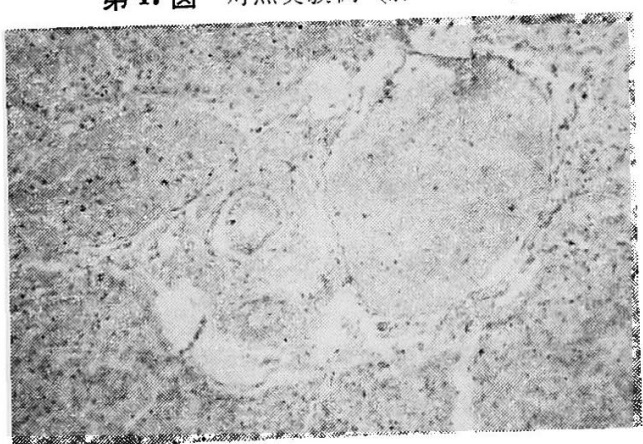


第 48 图本实験例（肝 $\times 100 ）$

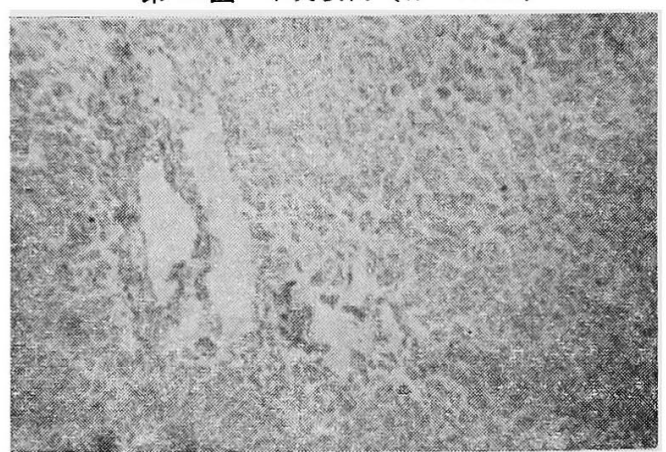

第 49 図 対照寒験例（腎 $\times 100 ）$

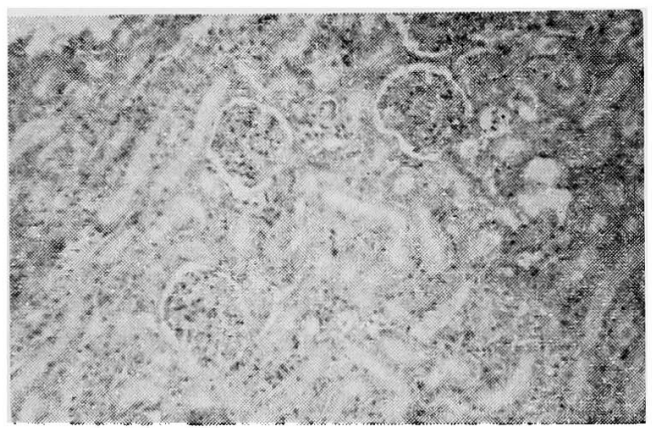

第 50 图 本实験例（腎 $\times 100 ）$

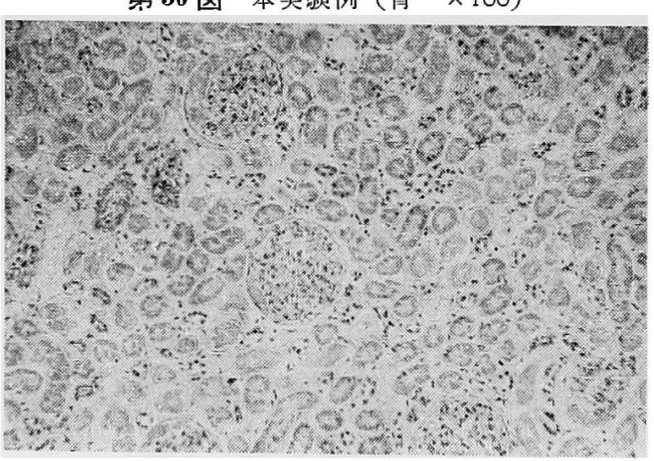

となり周囲につよい細胞浸潤と充血がみられ，出血性と なり赤血球を多数に混じて濾胞内出血の所見を呈する. (第 45 図)

本実験例の脾臓の緝織像には特に認むぐき異常所見は ない. (第 46 図)

肝葱については対照実験例では縕織内の中心静脈が強 度仙搪张して赤血球をるつて充満されて括る。赤血球は

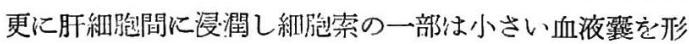
成している（第 47 図)
本実験例の肝臓の病理組織像は全例に諰むべき所見を 示さない（第 48 図)

腎葴に拈いては，対照実験例では全例に尿細管上皮の 浮膒性庿脹をきたし毛細管腔は狭少化し尿細管主部上皮 は一部硝子様变性をきたしている，系球体にはかなりつ 上い出血もみられ出血性米球体腎炎を思わせる所見を呈 する. (第 49 図)

本実軻例の腎病理組織像には特に著変を認めない。 (第 50 図)

\section{第4 章 総括ならびに考按}

現在リンパ系造影法に使用されている造影剂はほとん ぞ油性であり，従つてこれがリンパ管から胸管を経て血 管に入れば当然油性塞栓症が惹起されるものと考えられ る.

腸骨後腹膜腔リンパ系造影法にともなら油性塞栓症を 臨床的な立場から考察している文献をみると, Sheehan 6) らはリンパ系仕いわゆる filtering System であり渴 過器として働くので血流中に入る造影剤は少量であり， 油性塞栓症の危険性は少いと述べて括り，鈴木7)らは 注入された油性造影剂はりンハ管から流れて必ずいつれれ かのリンパ節内を通過して大きな脂肪球はリンパ節内の 組織に捕足され細網状組織を通り抜けた小脂肪球のみが 血流中に流入するわけであるから，このよらな超微粒子 性の脂肪球によつて塞栓症をおこす事は考兄られないと 述ベて㧍る。

それにも拘らず Wallance 8) らは110例中6 例飞脂 肪栓塞による朋梗塞を認めているがいづれも軽症で造影 剬は 1 週間以内に肺から消失しておる，彼らは脂胞栓塞 のおこるの焅影威の注入量と流入速度の大なる事に基 因すると述べている，また，Fuchs9) は20 例中 4 例 （2 例は虚脱，2 例は瑚梗塞）にこれを認わている。こと に肺梗塞の 1 例は重篤なもので本法施行直後, 全身の発 汗，速脉，胸部痛，喀血，呼吸停止が生し，翌日のレ線 像で左肺の末梢に実質性变化が認められ体温の上昇をみ て打る。特殊な治療はせずに 1 力月後には恢復している がな扮胸部痛と咽頭の恇脹感を訴えていたと言う，石 田 5) らは 174 例中 70\% に血痰が認められ，肺結核のた めに左肺全剔術をうけている症例に Lipiodol を注入し て胸内苦悶, 呼吸困難を訴劣りンパ 系造影施行後20日 目に死亡した症例を報告している.

次に本法にともなう油性塞栓症を動物実験を行つて考 察している報告をみると Goldberg ${ }^{10)}$ らの犬に叔ける 実験では術後 24 時間後屠殺して脸，肺，肝，脾，腎を 
摘出してレ線撮影を施行したところ，脳，䀒，脇，警に は造影散は認められなかつたが，肺にはかなりの变化が 認められ，特に注入された造影剂に対する湖梗塞の様相 を呈していたと報告している。

清水 ${ }^{11)}$ らは家鬼の実験で本法施行直後急死した動物 のレ線像で胸管より鎖骨下静脈，心臟、肺，肝動脈に浩 影剂が侵入する状洗が認められたと言う。絽織学的には 㨫，冠動脈には造影剂を認めなかつたが肺梗寒像が認め られたことより肺ェンボリーで死亡したものと考察して いる.また術後しばらく生存したものでは筲尿細管内に 造影剤の排泄されている像る゙㒛めている。

坂元 ${ }^{12)}$ らは 131 I-Popiodol を犬のリンパ管内に注入 し注入後3日，6日，11日，23日にそれ艺れ殺害して 各種践器 (肺, 脾, 肝, 留) への造影剂の移行を検討し たが，その結果は肢への提取率が王倒的に高いことを記 载している.

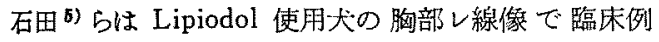
よりも遥かに著明な肺陰影を㒛めており，Osmium 染 色および Sudan III染色法にて組織学的に梌索し肋組

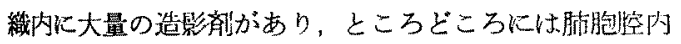

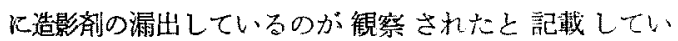
る.

私の笑缽では，造影济浅頸静脈内直接注入に上る対照

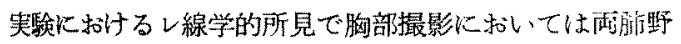
飞わたつて徽粒子状，〈も状，網状の相当著明な䧔影艺 呈したが, 腹部撮影では各贜器に相当する部位に異常陰 影を認め得ない。この事実は造影副が血流中に流入した 場合，肺に最も著明な変化をさたす事を示唆するもので

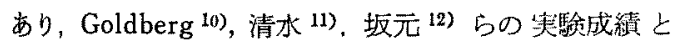
一致する。

右顎下部リンハ節に造影剂を注入する本寒験において 5 頍中1頭に軽度ではあるが右上肺野にビマン性陰影を きたした事は犬頸部りンパ菜造影法により油性塞栓症を 起し得る可能性があることを示するのである。しかしな がら 5 頭中 4 頭の胸部レ線像俚全く異常を認めない。こ れ社 Sheehan 6) や鈴木7)らの零らりンパ系の filtering System としての機檴によるるのと思考される.

レ線学的に把握し得ない油性塞栓症の影響を検討する ため重要䑏器 (肺, 脾, 肝, 腎) の病理組織学的検甞の 必要が生ずる.

対炤実験例では，肺は諸蔵器中最も著明な変化をきた 寸すすなわち，全て肺胞中隔が著明に肥厚し，らつ血が つよく肺胞粘膜の損傷がおこり，一部に組織のつよい壊
死を諗め，出血性肺炎の所見を旺しており，牌臟では脾 濾胞の中心が硝子様となり周囲につよい細胞浸潤と充血 が括こつて括り出血性となり赤血球を多数に混じて濾胞 内出血の所見を呈する．朋葴ではとくに中心部のうつ血 が萻明で中心静脈は著明飞搪掁して赤血咸をるつて冭满 されておる、赤血球は雪に肝細胞間飞浸潤し細胞索の一 部は小なる血液覆を形成している、照では全てうつ血が

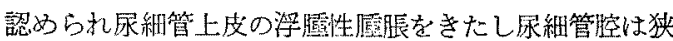
少化し，㲾細管主部上皮は一部硝子様变性をきたてい、 る。糸球体にはかなりつよい出血るるられ出血性糸球体 等炎を思和せる所見を呈する。

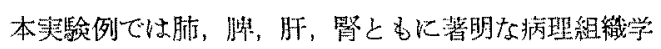
的所見を呈しないが，少くとも造影滆の注入量拉よび注

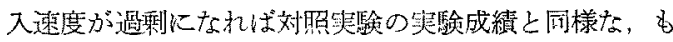

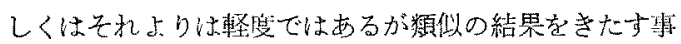

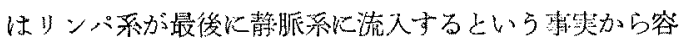
易に予測し得る。亦た滥影洞が清哌系心流入した場合， 掓循環を得て血流は脚跑火向うため油性造影剂の脂肪球 は第一の関門たる肺胞にて阻止され肺に最るつよい変化 をきたす結寒となる。

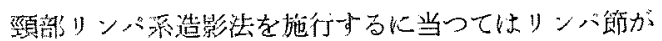
浩影䜪の脂肪球を阻止する濾過装管としての機能を充分

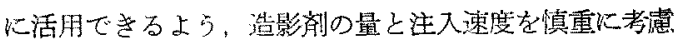
して行党ば臨床的飞充分応用可能であると考员る。

\section{第 5 章 結 論}

1）本寒駼で士本法施行後油性塞桎症に上り死亡せる

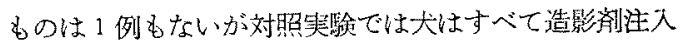
直後上り濑次呼吸促泊を盗強し24時閒以内に死亡する。.

2）胸部レ線像に関して本䒠験では 5 例中 1 例儿右上 肺野にわずかなビマン扯陰影它認めたものがあつたが他 は異常を諰めたい，対照実歌では全例に雨肺野，とくに

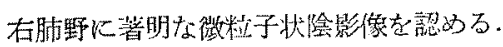

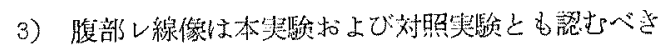
所見はない。

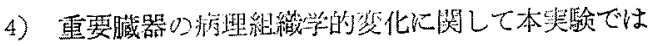

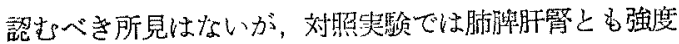
のらつ血を主体とする所見を譛めるがとくに腽の組織像 にその程度が著明である。

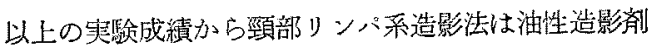
を使用する限り，油性塞柽症の扣こりうる可能性はま奴 がれ得ないが，注入量ならびに注入速度が過利にならぬ 上らに慎重に寸机代何ら危険なく实施されるものと結論 される。 


\section{第 1 章 緒論}

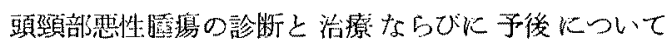
は，頸部リンバ節転移の間题を然視する本恃できない，

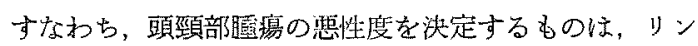
パ系への転移能力がすべてではないが決定的要因の一の である以上，頸部りンパ節に和ける病变の摭りを正確に 把握することは重要な意味をるつ。

私は頭頸部悪性遁演の頸部リンパ節転移ならびに, 项 部膘㿇をきたす疾患に対する猃断法として頸部りンパ系 造影法を陚み，ての臨㦿的価值について述べる。

\section{第 2 章 実験方法}

A 術前処篧

造影㕮によるヨード過敏症テストを行ら。すなわち， Popiodol を皮内注射しその皮内反店を検してヨード過 敏㱑の患者には本法を施行しない。

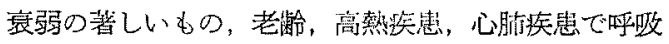
困難のあるものは本法を施行しない。

耳分後部の剃毛を行ら。

本法の所要時閆《 1 時間 30 分から 2 時間を要するの で、患者を安静比させるためにラボナ2 鉆内服, 弱ナル スコ0.5cc の皮下注射を行う。

感染予防のため抗生物貿の投与を行 5 .

B 莖新リンパ系造影法の手技4) 22)

平分附着部比 2 力所で $0.5 \%$ Xylocain 浴液と $11 \%$ Patent blue V を等量に混ぜた溶夜を $0.2 \mathrm{ml}$ あて皮队 注射する。注射部位を求心性に10 分間ーマッサージする。 次に耳分附着部より約 $5 \mathrm{~mm}$ 後方で耳界附着部の中閒 よりト方へ約 $3 \mathrm{~cm}$ の皮膚切開を拝き皮下組織を䟝離し て青染したりンパ管を見つける.

リンバ管は基底部を剶離せず上壁と側壁をたん念沉約 $1.5 \mathrm{~cm}$ にるたつて剥離する。基底部を剥離 しないのは 次に行ら注射針刺入の際のリンハ管の可動性を防ぐため である。

注射猃媇新品の Mantoux氏 反应用注射針を利用与 るが，刺入に先立ち眼稍用䋧系をりンバ管の中枢側と末 梢側で基底部の組織似軽くかけ，中枢側の絹糸を挙上し てマッサージし，リンパ液のうつ滞を就さすとリンパ管 はかなり怒脹してくる，そこで末梢側の絹糸を挙上し て，Mantoux 氏反応用注射針の穴を上部に向けてり ンバ管に刺入する。針は末梢側の絹釆にて結紮固定す る.
造影剂 Popiodol の注入に当つて，あらかじめ注射筒 と注射針との間にアトム鼻注用カテーテルを装置して括 く，造影凧の注入量は $0.08 \mathrm{ml} / \mathrm{kg}$ (体重 $50 \mathrm{~kg}$ で 4.0 ml) として全量注入するに 1 時間 30 分から 2 洔間かけ る. 注入後皮旊縫合を行う, 造影洞注入後撮影時間证原 則として 2 時間と 24 時間とする。

C 撮影殸犆打よび撮影条件:

撮影装置扣よび撮影条件は次の如くにする。

a) ᄂ線発生装置: 東芝 $\mathrm{KXO}-8$

b) 管球: DRX-70 ロータノード焦点 $2 \times 2 \mathrm{~mm}$

c) 散乳線除去法: 多重シャッター 6: 1MSグリ ッド

d）塔感紙：極光製 FS

e) フイルム: さくら X-レイ・タイプ $\mathrm{Y}$

f）管電生：前後面 $90 \mathrm{KVp}$ 侧 面 $90 \mathrm{KVp}$ 斜位 $\mathrm{A} \quad 55 \mathrm{KVp}$ 斜位 $\mathrm{B} \quad 90 \mathrm{KVp}$

g) 管笔流: 前後面 $100 \mathrm{~mA}$ 側 面 $100 \mathrm{~mA}$ 斜位A $300 \mathrm{~mA}$ 斜位 B $100 \mathrm{~mA}$

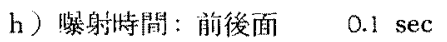
側 面 $0.08 \mathrm{sec}$ 斜位A $0.1 \mathrm{sec}$ 斜位 B $0.08 \mathrm{sec}$

i) 篤点フイルム間距離: $100 \mathrm{~cm}$

D 撮影力向

撮影方向は第 51 図の如くで，前後面では体位は坐位 又は仰卧位で行う．頭部正中矢状面はレ線フイルムに垂 直とし外後頭隆起をフイルムカ七ッテに密着せしめる. レ線中心線は頭部正中矢状面を通過し箅尖部に向つて照 射する，側面では体位は坐位又は検側它下にした側卧位 とする．頭部正中矢状面はレ線フイルムに平行とし肩を フイルムカセッテ下端に接着せしめる。レ線中心線は非 検側外耳道を貫きフイルムに垂直に照射与る。斜位Aで 法体位は坐位又泟仰卧位である。独冕水幵面はフイルム

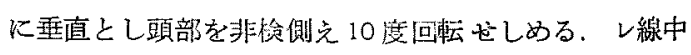
心線は険側下哿角を貫きフイルムに垂直に照訝する。 斜位 B では体位は坐位又心检側定下にした側馷位であ

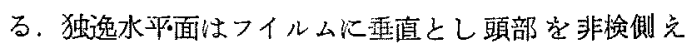


第 51 図頙部りンバ采造影撮影方向

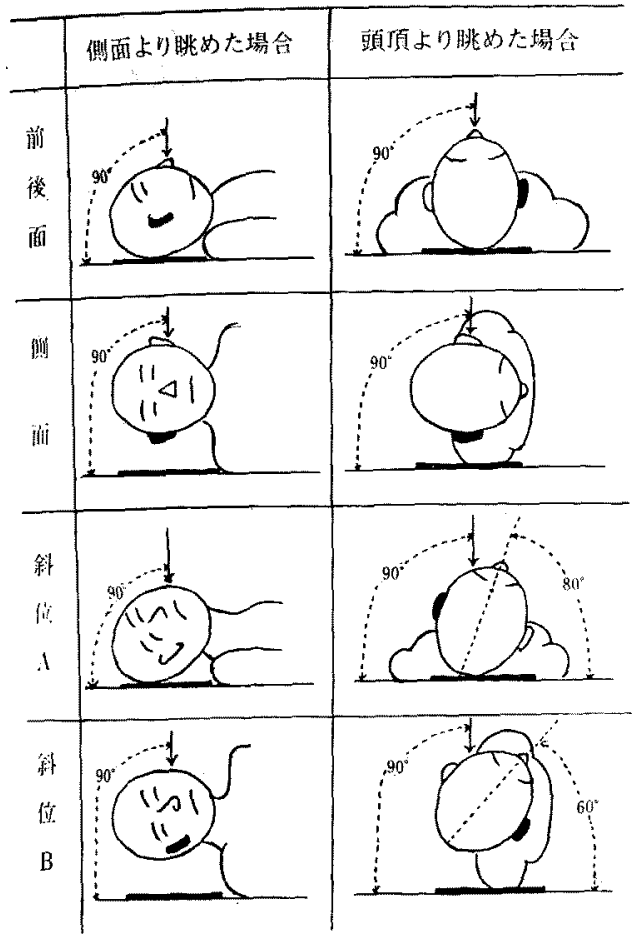

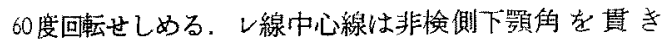
フイルムに捶直に照射する。
前後面と側面の影像に括け当钼察目的は頸部りンバ節

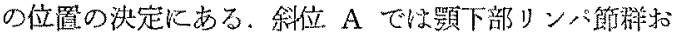

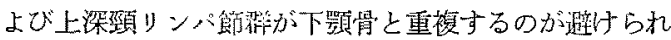

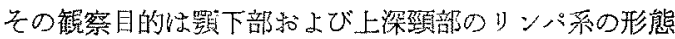
とリンパ節の内部構造観寗のためである。斜位 B は上

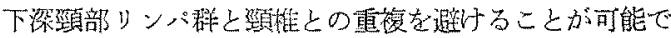

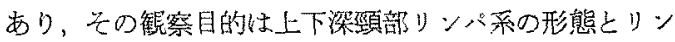
パ節内部桠造にある。

\section{第 3 章 実 験成啨}

ヒト頸部リンパ系造影法を施行㤂る怔例数は 24 例で,

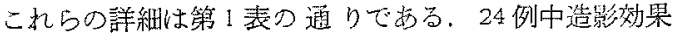

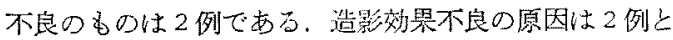

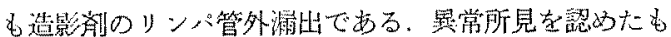
のは24例中 10 例で他は正筷である，副作用としては，

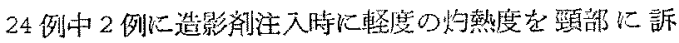

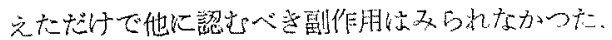

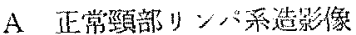

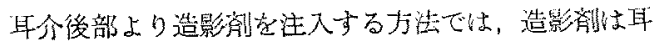

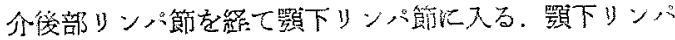

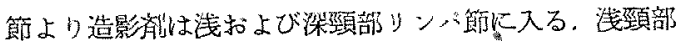
リンハ節は顎下りンハ節上り鎖骨に间つて外下方に斜め

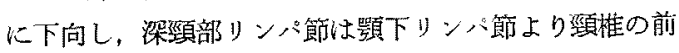
外側に沿つて鎖骨に向つて垂直に下向する，従つて耳介 後部りンバ管より造影剂を注入する正常頸部りンパ系造

第 1 表 ヒト镍部リンパ系造影自睮例

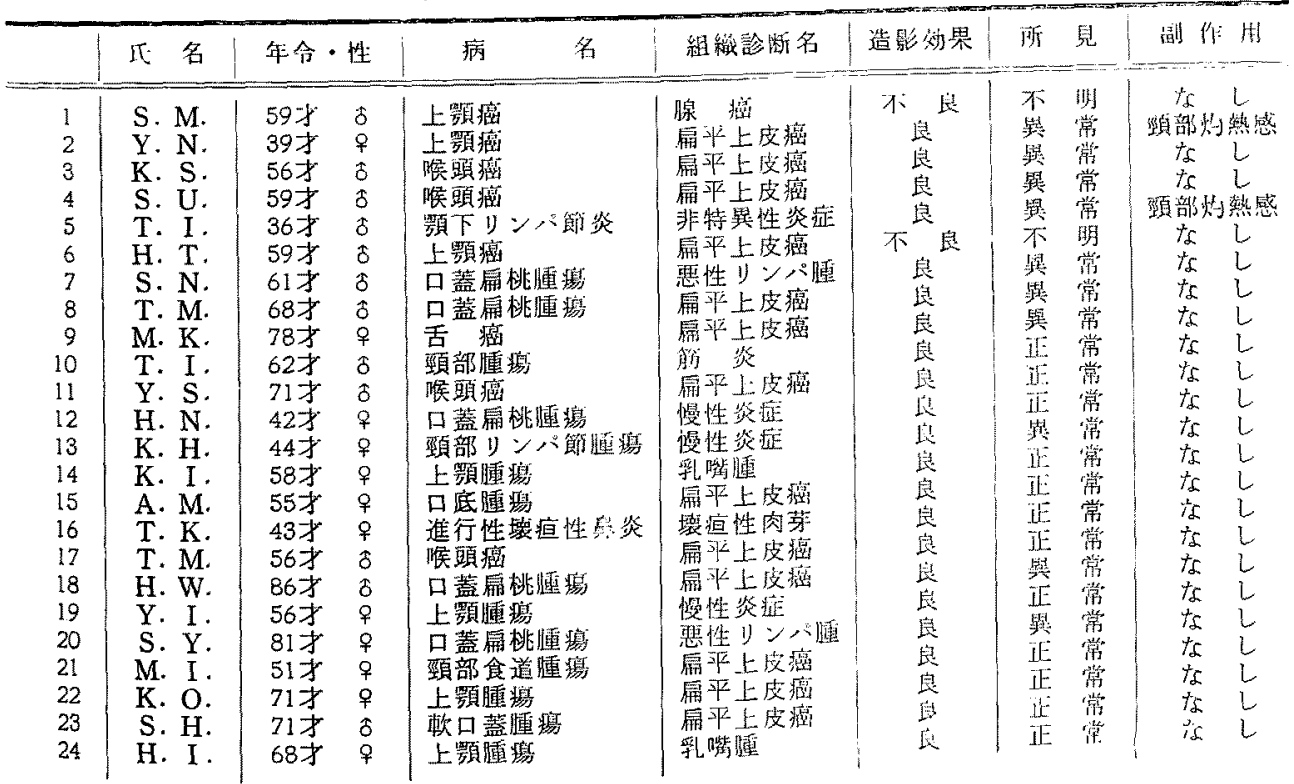


影法ではその前後面像扣よび斜位 A 像に打いては, 顎 下リンパ節群を頂点として，鎖骨の内側 $1 / 3$ を底辺とす る縦に長い三角形として頸部りンパ系が造影される．側 面像では浅頸部リンパ節は頸椎に沿つて下向し頸椎の陰 影と完全に重複する，深项部リンパ節は頸惟の前で気管 に重複して下向する，斜位 B に批いては顎下リンパ節 碓は検側の下顎角と第 II 頸惟の間に描出され，この顎下 リンパ節碬から二条のリンパ節の連鎖が下向する。他 方第 VI，第 VI頸椎の前に一群のリンパ節が存在する．こ れら二条のリンパ節連鎖と一群のリンパ節 上浅捛よび深
頸部リンパ節である.

頸部リンパ系造影法で描出されるリンパ 節の数は 40 筐ないし 50 籄でありその大きさは米粒大から小指頭大 である.

本法にて造影不可能であるリンパ 節は後頭部リンパ 節, 頤下リンパ節, 䐅頭前リンパ節, 耳下腺リンパ節, 頓部リンパ節である，即ち，比較的浅在性で正中部のリ ンパ節群と臓器所属りンパ節群法大体に批いて描出不可 能である. (第 52 図)

第 52 図 注入後 24 時間 左澒部リンパ節像

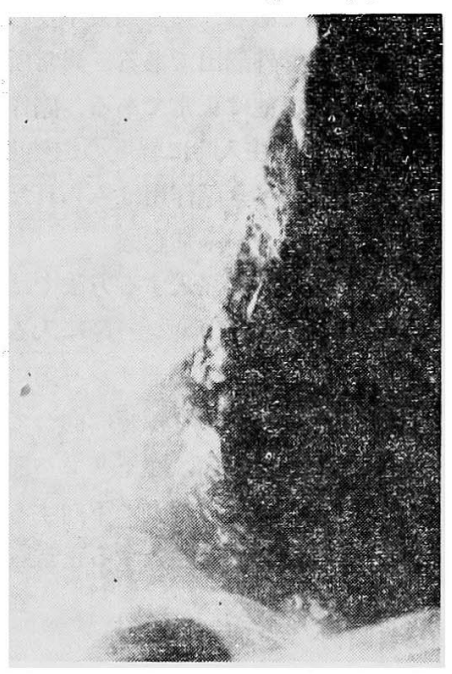

a 前 後 面

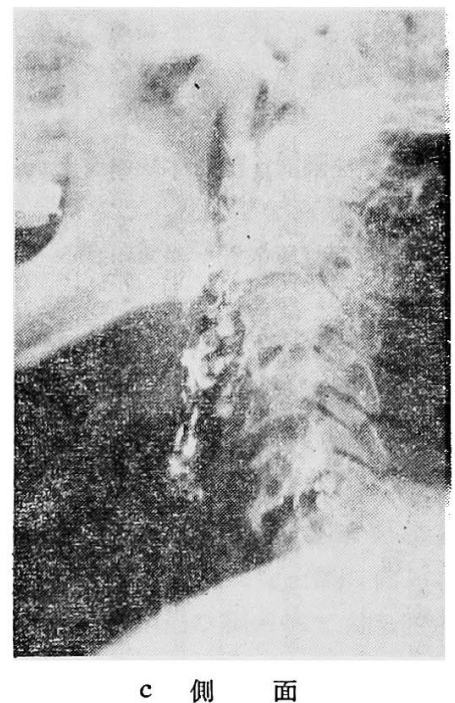

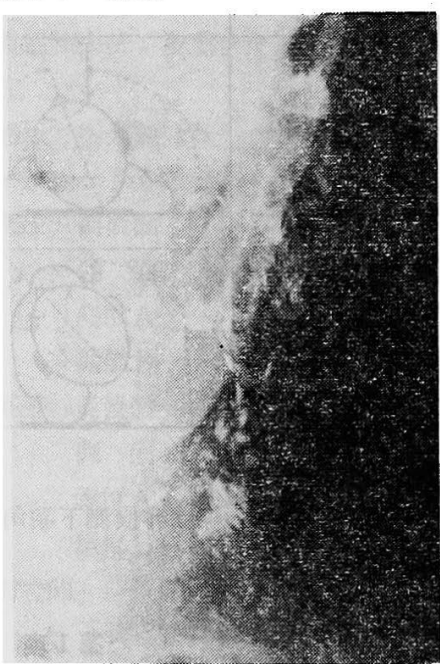

$\mathrm{b}$ 科 位 $\mathrm{A}$

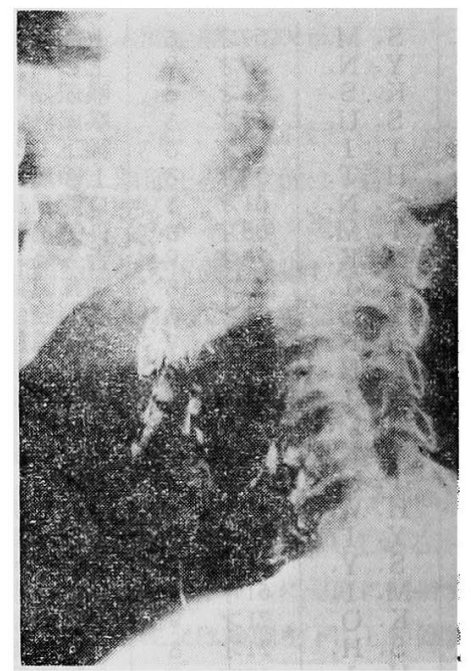

d 斜 位 B 


\section{B 異常頸部リンパ系造影像}

頸部リンパ系造影法を施行した 24 例中異常所見を認 めたすのは10例である. そのらち 7 例を撰択してその 造影像について述べる.

\section{症例 239 才子 左上顎癌}

組織診断は拥平上皮癌である。造影剂注入後 24 時間 の前後面撮影による造影像はほぼ正常の頸部リンパ系造 影像であるが, 顎下部リンパ節群の一つはドーナッ型中

第 53 図 ドーナツ型中心欠損像
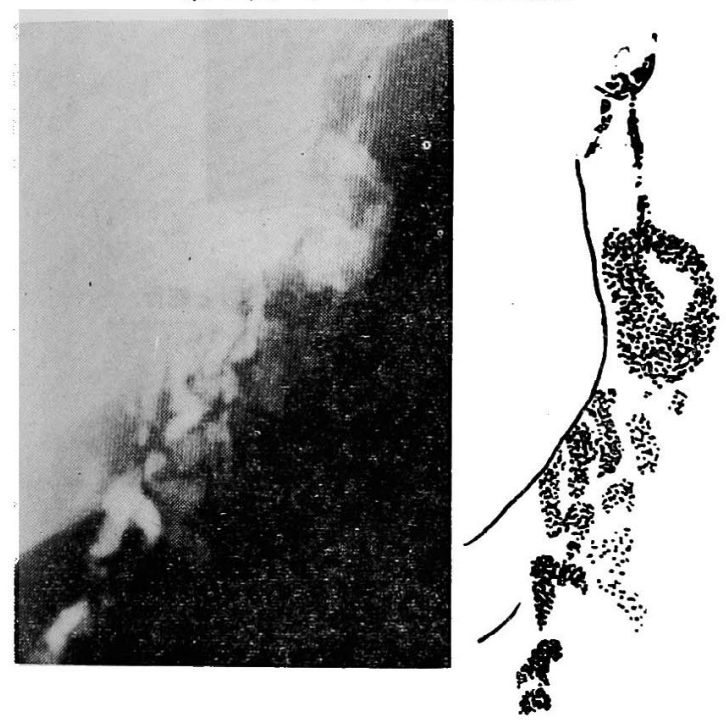

第 54 図 偽性虫喰い状所見
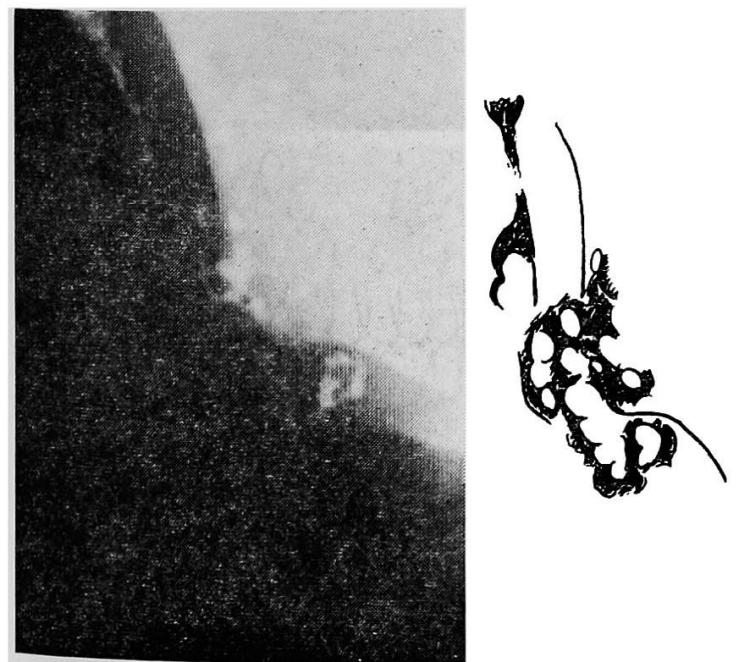

心欠損像を呈する。（第 53 図） 症例 356 男子 喉頭癌

組織診断は扁平上皮癌の患者で，䐅摘後 29 日目にリ ンパ系造影法を施行し，造影剂注入後 24 時間の前後面 (第 54 図) 側面 (第 55 図) の造影像である、下深頸り ンパ節群は手術侵翼および ${ }^{60}$ Co 照射のため造影されて おらない，顎下部又は上深頸リンパ節は一見虫喰い状様 の所見を呈しているが, 術後 1 年 6 カ月になる現在, 再 発や頸部リンパ節転移の兆候もなく，良好に経 過している点から，偽性虫哴い状所見でいわゆ る正常偽陽性リンパ節と考えられる。

\section{症例 4 59才 男子 涘頭癌}

第 56 図は組織診断が扁平上皮癌で斜位 B 撮影に氺ける造影膈注入後 24 時間の造影像で ある，造影威はなおリンパ管内にのこり，いわ ゆるリンパ管内残存像を呈する。しかもリンパ 管数の著明な增加と緛状化を認める。これは明

第 55 图偽性虫喰い状所見
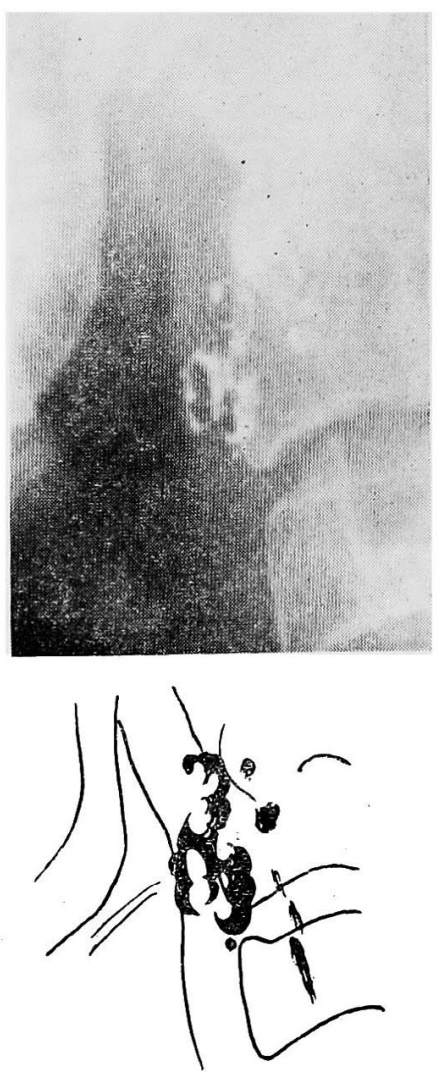
第 56 図りンパ管数の增加と網状化

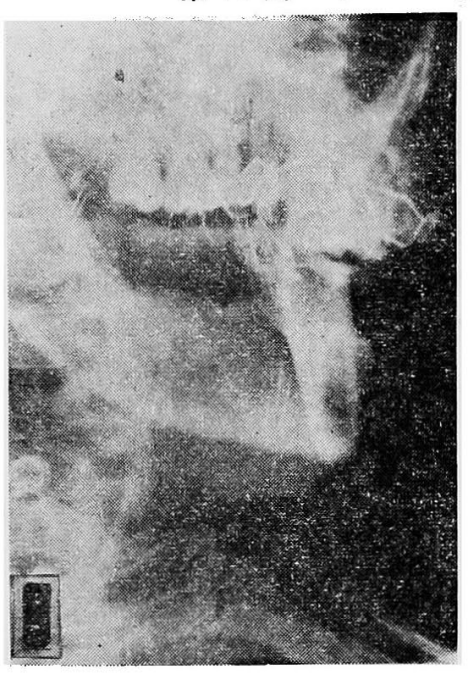

第 $\mathbf{5 7}$ 図リンパ管の断絶と拡張
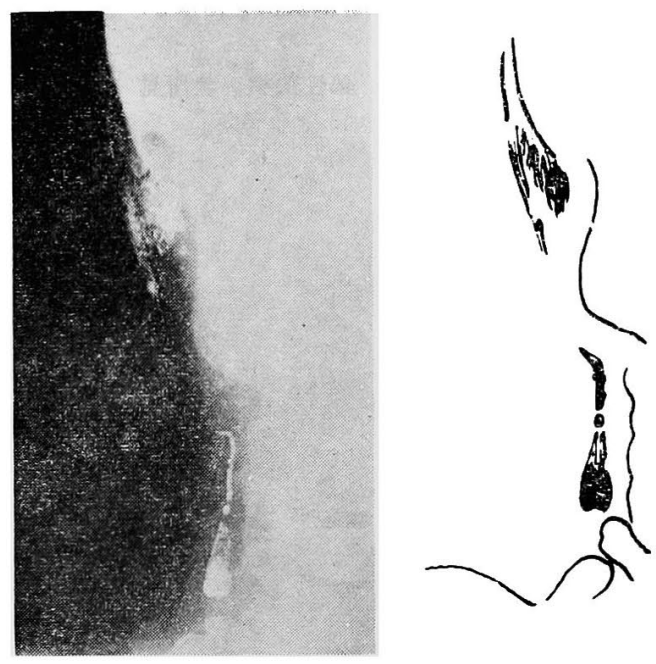

らかにリンパ系の通過障害によつて挂こされたリンパ管 の異常所見である.

症例7 61 才 男子 右口蓋扁桃腫盼

組織診断は悪性リンパ腫である，造影削注入直後の前 後面撮影による造影像（第 57 図）をみると，下深頸り ンパ節の造影剂充盈け充分であるにかかわらずその輸出 管が羿められない. 輸入管は通過障害のため断絶し㹡張 像を呈する. 第 58 図は造影剩注入後直らに撮影した斜 位 B における造影像である. 顎下リンパ節から上深頸 リンパ節に向らリンパ管は大きく迁回し蛇行する。これ
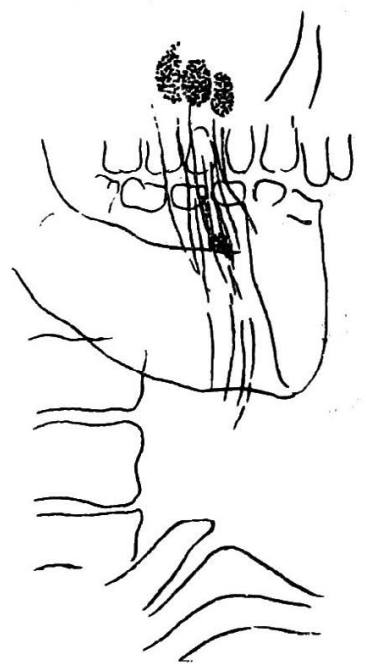

第 58 図リンパ管の迁回と蛇行
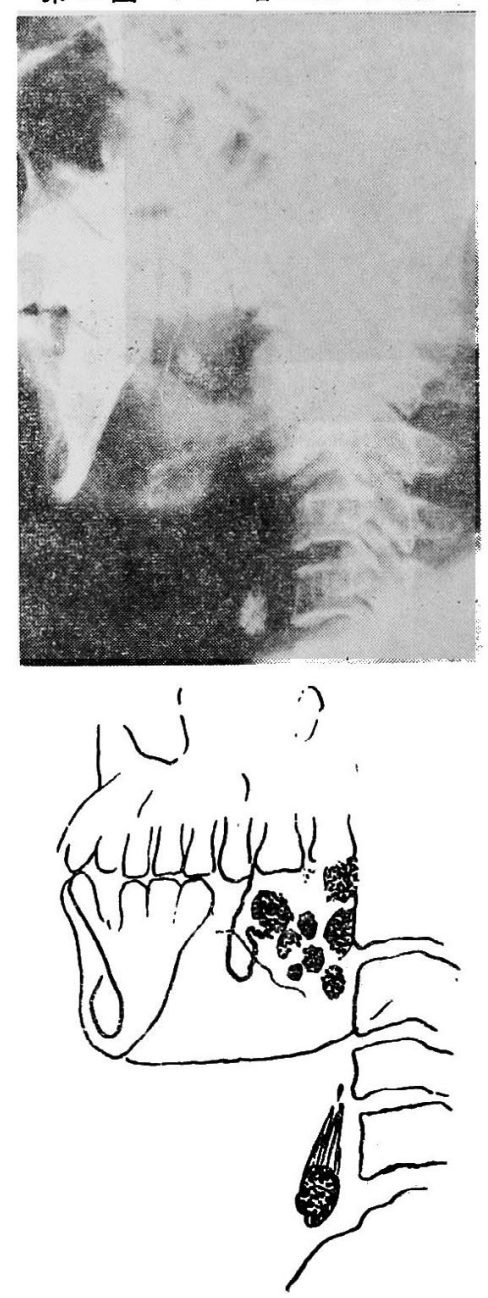
第 59 図雨漏り様所見
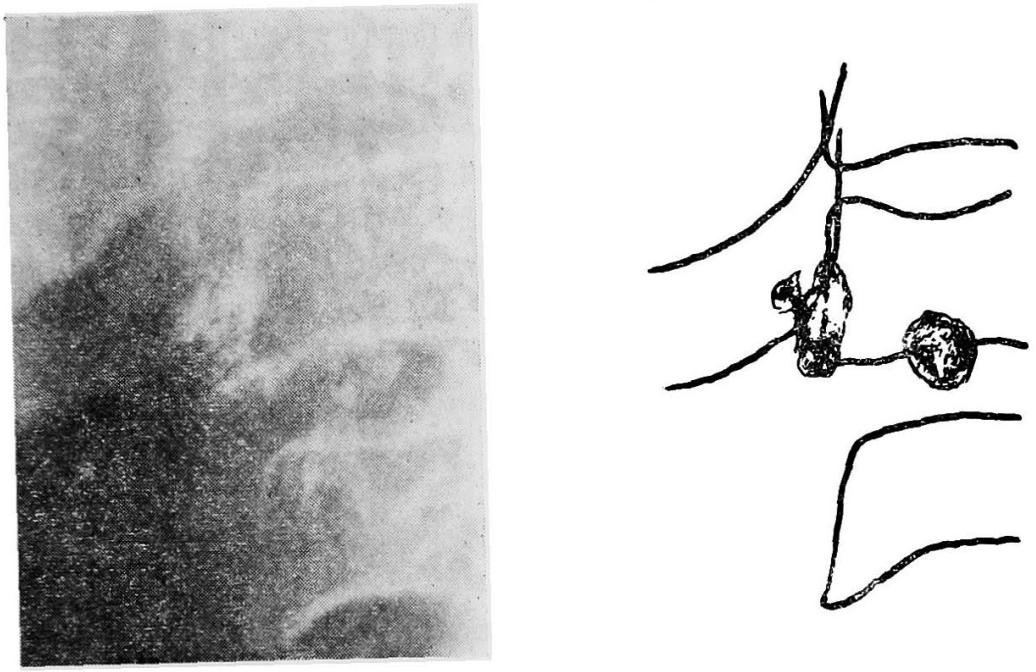

第 60 图雨漏り粎所見
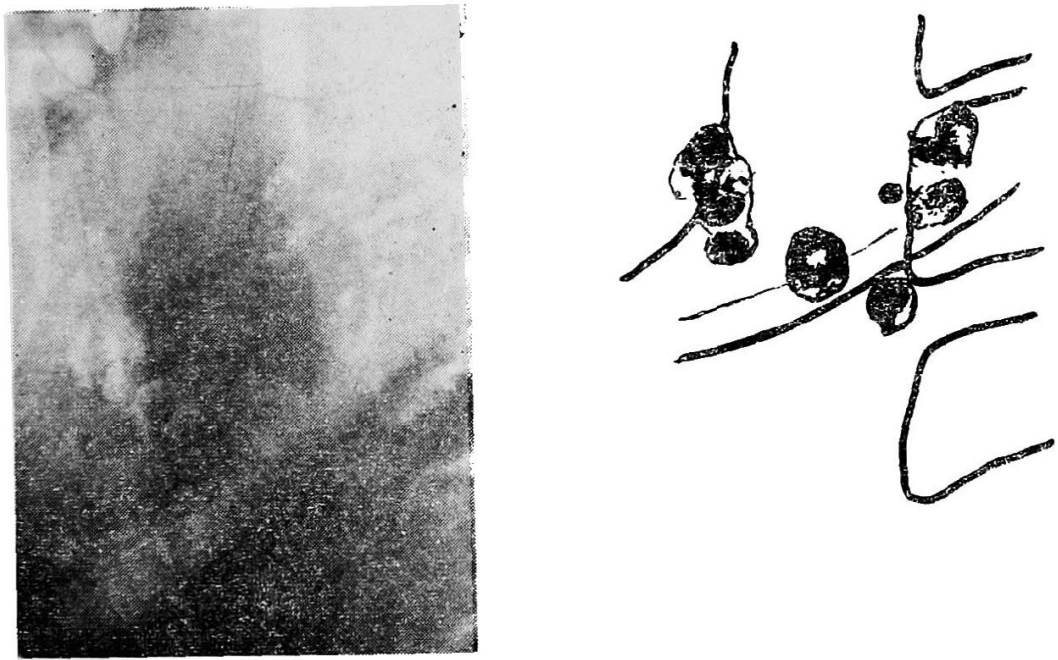

第 61 図虫喰い状所見
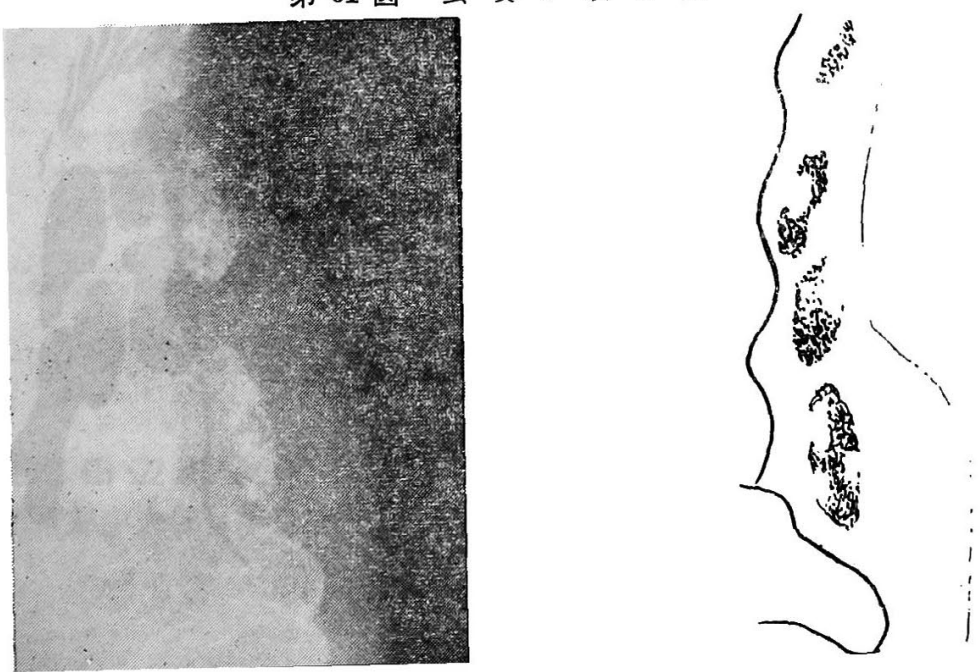


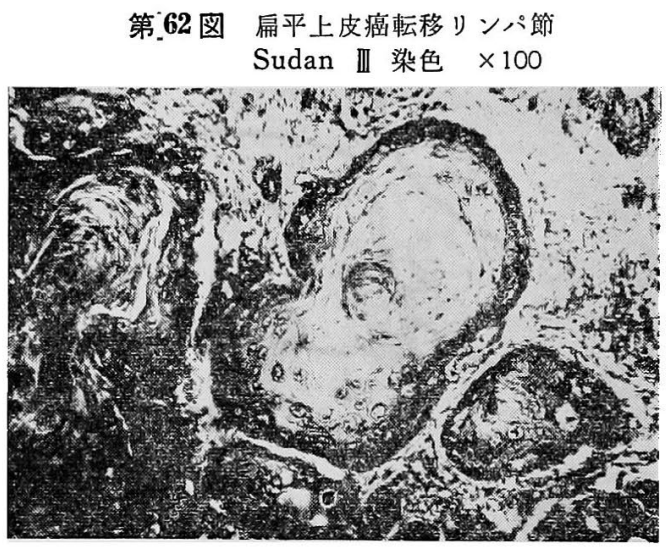

は上深頸リンパ節と下深頸リンパ節の間に介在する深頸 部リンパ節の影像が明らかでなく全欠損を呈している事 からこの部に通過障蹇があることが推測される．造影绪 注入後 24 時間で撮影した側面像と 斜位 B 像は第 59 図 と第 60 図にみるごとくである.上深頸リンパ節は典型 的な雨漏り状所見を呈する.リンパ節辺縁は非常にスム

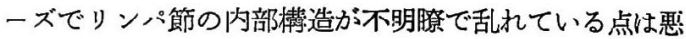
性リンパ逓がリンパ節の実質から発生すると言う病理学 的変化と全く一致するむのである.

\section{症例 868 才 男子 左口蓋扁桃腯瘍}

組織診断は扁平上皮癌である，造影剂注入後 24 時間 の前後面撮影による造影像である.（第61 図）深頸部り

第 63 図 リンパ節数の增加と副行枝形成
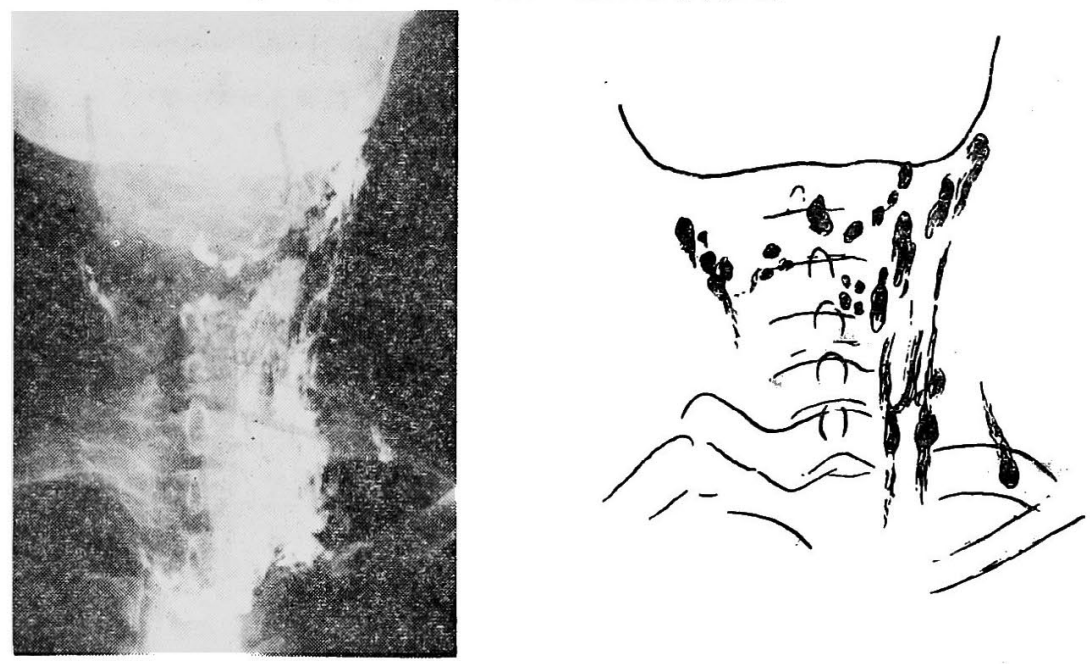

第 64 図りンパ節の無橉造化
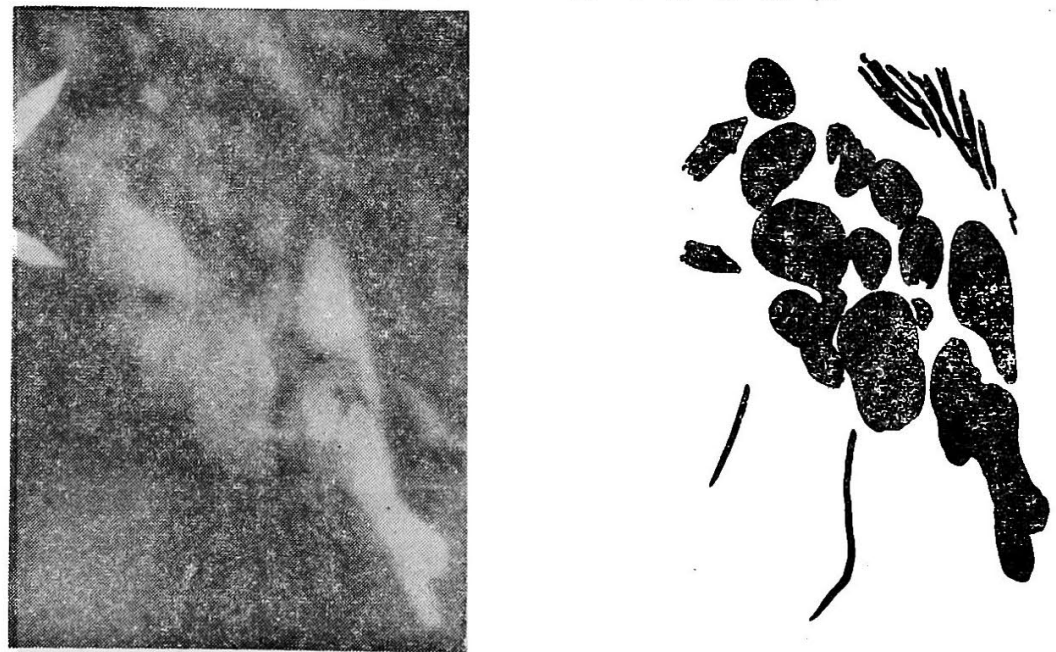


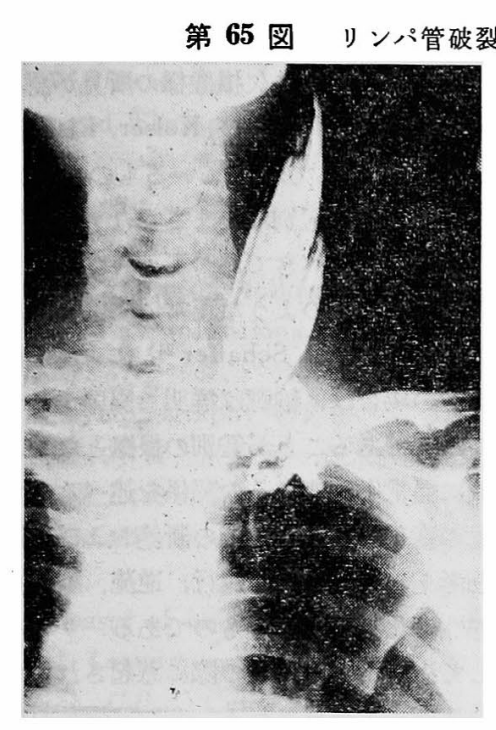

ソパ節の形態をみるとリンパ節辺縁部の充盈欠損はあた かも虫が哙つたよらな不規則な輪廓を形成する，すなわ ち典型的な虫喰い状所見を呈する。

本症例では頸部リンパ系造影法施行後 8 日目に造影り ンパ節摘出を行ら機会を得たので摘出リンパ節にズダン 染色を行つた．その結果は第 62 図の如くそのリンパ 節組織には定型的癌性転移扁平上皮癌があり，このよう に明らかに癌浸潤のあるところには造影剤の侵入は認め られない.

\section{症例9 78 才子 舌癌}

組織診断は扁平上皮癌である。造影斉注入後 24 時間 の前後面撮影による造影像（第63 図)ではリンパ節の数 の堌加と副行枝形成のため，正常では造影されない反対 側のリンパ節が造影されている．第 64 図は造影剬注入 後 24 時間の側面像における上深頸りンパ節群であるが リンパ節は著明に脑大し節内の哭構造化が認められる。

症例 1344 才子 左頸部りンパ節盉浧

組鐡診断は慢性炎症である. 造影凧注入後 24 時間の 前後面撮影による造影像（第 65 図）ではリンパ管の通 過障害による著明なリンパ管破裂像が認められる．鎖骨 上部の下潹頸リンパ節群は数の増加と無構造化が認めら れる.

\section{第4章 総括ならびに考按}

ヒト頸部リンパ系造影法の歴史は浅く, 1960 年 Battezzati と Pietorantonie が水溶性造影郕を使用して行 つたのが最初である.1963 年米国で Jackson と Wallance ${ }^{12)}$.が, 次いで同年スイスで Fisch 14) 15) と Buo- no 4) が耳分後部リンパ管より油性造影膈を注入してい る.

我が国では1963年, 北村・金子 16) らが腯大せる下顎 リンパ節に20\%モリオドールを注入乙頸部リンパ系の造 影に成功しており, 同じく鈴木?らは耳介後部リンパ 節にポピオドールを注入している.しかしながら頸部り ンパ系造影法の臨床的価值について論じた文献はみあた らない。

私は耳介後部リンパ管より油性造影剂ポピドオールを 注入してヒト頸部リンパ系造影法を行つた. 自験例 24 例中に認められた所見を要約すると次の通りである.

正常頸部リンパ系造影像では耳後部リンパ節, 顎下 リンパ節, 浅頸部リンパ節, 深頸部リンパ節が造影可能 である. 描出されるリンパ節の数は 40 箇ないし 50 箇で ありその大きさは米粒大から小指頭大である. 本法にて 造影不可能のリンパ節は比較的浅在性で正中部のリンパ 節群と蔵器所属リンパ節群であるがこれらのリンパ節は 広沉性全摘において大体摘除されてしまう部分であるか ら臨床的にそれ程問題にしなくても良いと思われる.

異常頸部リンパ系造影像を示したものは 24 例中 10 例 であるがその異常所見は次の通りである.

1)リンパ系の通過障害

a) リンパ管数の增加执よび網状化

b ）リンパ管の走向異常（破裂，断絶, 㹡張, 蛇 行, 副行枝形成)

2）虫喰い状所見

3）雨漏り様所見 
4) 無構造化

5）正常偽陽性リンパ節

a) 偽性虫喰い状所見

b) ドーナツ型中心久損

リンパ系通過障害のうち、リンバ管数の增加之網状化

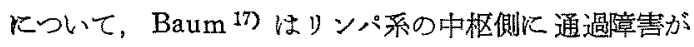
ある場合は 24 時間から48時間後のリンパ管内残存像 を認めて招り，山下 ${ }^{18)}$ らはリンハ管数の增加する場合 は大部分は中枢側リンパ管のリンハ液通過障害による事 が多くレ線所見ではリンパ管は絧目状を是するのがほと んと゚であると述べている。

リンパ管の走向異常については，リンパ系に通過障害 のある部よりも末佾では，リンパ管は拡張し内王立進の ために静眽と同粎核著しい蛇行を示す場合がある。通過 障害が更汇進むとりンパ流の逆流がおこり，逆流したり ンパ管と他のリンパ管との吻合枝を通じて副行枝が発達 したりするし，遠くの分枝の場合には大きな迁回像とし てみられたりする。

虫哙い状所見について，この陰影欠損は癌転移の最も 特徽的な像で，リンバ節式縁部の陰影欠損として認めら れる.この陰影欠撮は辺縁りンパ洞からはじまるため造 影剂の充盈欠損像はあたかる虫が愴つたような不規則な 輪郭を形成する、このような損像が1コあるいは数コ みられる状態を虫喰い状と言う表現でしばしば説明され る.

雨㴮り様所見とは悪性リンパ畽に特徽的な所見であっ

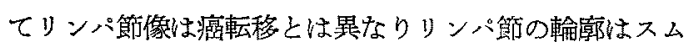
一ズに保存され，内部構造は不明膫な泡抹状，レース状 あるいは蜂简状となり，更には雨漏り様すなわち gohst -like な所見を呈する。

リンパ節内部が然構造陰影として観察される場合は異 常所見であり、リンパ洞の抁大に上るものである、市な わらリンパ洞の部分的拨大のある場合には斑紋状とな り，この斑絞状陰影が重複した場合は無構造にみえ, 更

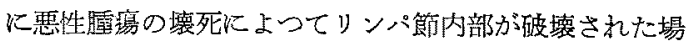
合に为観察される。

正常偽陽性リンパ節については，正常リンパ節でむ時 によつて異常を思わせる所見を示すことがある。これを 正常偽陽性リン八節という，そのらち偽性蝓い状所見

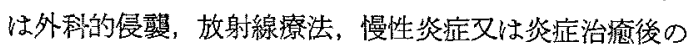
リンパ節に線維性変性や脂肪性変性などのごとく退行変

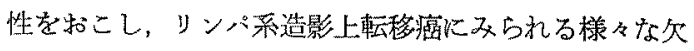
損像を招来するるのである。ドーナッ型中心欠損につい
ては、リンパ節門の発達のつよい場合にはこの部に造影 剂は充満せず節門に欠損像様の所見が認められる。これ は Kaindle 19) らおよび Keiser, Fischbier ${ }^{20)} か ゙$ krabbenform として示しているるのでかかる中心性欠損 之辺緑性欠撌の区別はさまざまな方向からの撮影像们っ いて検討されるべきであつて，時には搪大撮影も試及る べきである.このような正常偽陽性りンパ節像と病的陰 影欠損像の鑑別は Schaffer ${ }^{21)}$ による之正常偽陽性リン 八館像の場合は，輸廓は焦明で規則正しく部位はしばし ば中心部であることが鑑別の根拠となると述べている。

次港常像之疾患之の関係を述べる。すなおち、リン 管の変化ではりンパ系の断絶扣よび通過障害が悪性所 見之考光られ，拨張，蛇行，逆流，副行枝形成过回な之゙ も悪性変化を暗示するむのである、リンパ管の破裂は主 として注入圧力の過大の際莒起されるが慢性りンカ節 炎の症例にる発見される。リンパ管数の增加乱よびリン パ管からの漏湿も罢常であるが必ずしも悪性病変の場合 のみとは限らない、リンパ節の悪性所見には陰影欠損, 辺縁不整，構造不整，無構造化，その他に良性でる久ら れる腫大抏よび数の增加が認められる. 正常りンパ節で も偽陽性りンパ節として㙳性虫嗆い状所見とドーナッ型 中心欠損像を認めるがこれらは和招む祊欠損部の辺縁が 焦明で一見して病的リンメ゚節と鑑別が可能であることが 多いが，多方向からの撮影像と桩大撮影像を検討するこ とが必要である場合もあると思われる。

\section{第 5 章 結 論}

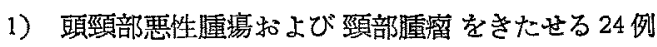
に钼部りンパ系造影法を試みた。

2）本法注函めて早期の頸部りパン系病変の診断には ある程度の限界がある。しかしながら頭頸部悪性嗹場の 頸部リンパ節転移の検索および頚部リンパ節炎との鑑別 にはかなり有力な検查法である。

\section{文献}

1) 吉井功：耳鼠咽知科領域に括けるリンパ流の臨

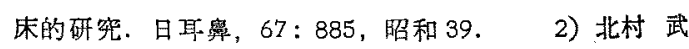

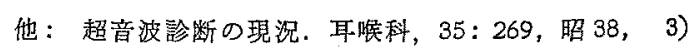
Kimmonth, J.B.: Lymphangiography. Clin. Sc. 11: 13, 1952. 4) Fisch, U.P., and del Buono, M.S.: Zur Technik der Cervical Lymphographie. Schweiz. med. Wschr. 93: 994, 1963. 5) 石田 修: リンパ系造影後の副作用。日医放, $24: 982$, 昭 39. 6) Sheehan, R.: The Use of Lymphography as a Diagrostic Method. Radiology, 76: 47, 1961. 
鈴木填二他：リスパ系造影用ポピオドールについて： 17, 昭 39. 8) Wallance, S.: Lymphangiograms: Their Diagnostic and Therapeutic Potential. Radiology, 76:179, 1961. 9) Fuchs, W.A.: Complication in Lymphography with oily contrast media. Acta Radiologica. $57: 427,1962 . \quad 10)$ Goldberg, M.E.: Pulmonary infarction following lymphangiography in dogs: Its implications in human studies. Radiology, 86: 479，1963.11) 清水直太郎他: 子宫䁰癌に拈ける Lymphography の応用。癌の臨床, 10:659, 1962. 12) 坂元正一他: 鈴木雅洲編集: リンパ系造影法の臨床. 103：1965, 医学害院. Jackson, L.: Cervical lymphography. Laryngoscope, $73: 926,1963 . \quad 14)$ Fisch, U.P.: Cervical lymphography in cases of laryngo-pharyngeal carcinoma. Jaunal of Laryng and Otolog. 78: 715, 1964. 15) Fisch, U.P... Cervical lymphatic system as visualized by lymphography. Ann. of Otolog. rhinolog. and laryngolog., 73: 869, 1964 . 16) 北村武, 金子敏郎他: 形部リンバ管造影法. 気食会 報, 14:253，昭 $38 . \quad$ 17) Baum, S., Bron, K.M., Wexler, L. \& Abrams, HL.: Lymphangiography, cavography and urography. Radiology, $81: 207$, 1963. 18) 山下久焳他: 鉿木弱洲編集：リンパ系 造影法の䠄床, 144: 1965, 医学書院. 19) Kaindl, F., Mannheimer, E., Pfleger-Schwarz, L. und Thurnher, B.: Lymphangiographie und Lymphadenographie der Extremitaten. Georg Thieme Verlag. Stuttgart. 1960. 20) V. Keiser, D. und Frischbier, H.J.: Der Wart der Lymphographie bei der Metastasensuche, Fortschr. Rontgentr, 110, 299, 1964. 21) Schaffer, B., Gould, R.J., Wallance, S., Jackson, L., Ivker, M., Lebermann, P.R. \& Fetter, T.R.: Urologic applications of Lymphadenography, J. Urol., 87, 91, 1962. 22) 坂元正一 他 : 直接リンパ系造影法の手技について，産と婦，31：784， 昭39.23）石田修他：リンパ系造影法に上る悪

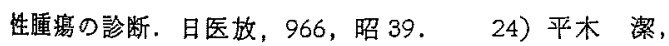
入野昭三: リンパ系造影法 (Lymphography) の臨床 応用一自家経験例を中心とした総説一、䍃合㹂床，12： 2218，1963. 25）鉿木㥧二 他：Lipiodol Ultra -Fluide (Ethiodol) によるリンパ采造影について。 日 医放, 24, 275, 26) Zheutlin, N., Shanbrom, E.: Contrart Visualization of Lymph Nodes. Radiology, $71: 702,1958 . \quad 27)$ Shanbron, E.: Radiographic studies of the lymphatic system. Archives of internal medicine 104: 598, 1959.
Malamos, B.: Lymphadenography (Its uses in haematology) Britsch medical Journal 1360, 1959. 29) Jacobson, S.: normal Roentgen anatomy of the lymph vessels of Upper and lower Extremities. acuta Radiologica, $51: 321,1959 . \quad 30)$ Viamonte, $M$. et al: Lymphography: its role in detection and therapeutic evalution of carcinoma and neoplastic conditions of the geniourinary tract. Journal of Urology 87:85, $1962 . \quad 31$ ) Fischer, H.U. et al.: contrast radiographic demonstration of a lymph node Metas tasis.J. A.M.A. 175: 327 , 1961. 32) May, E.R. et al: Lymphamgiography as a diagnostic adjunct in urology. J. of Urolog. 87, 208, 1962. 33) Jackson, L. et al: The diagnostic value of lymphangiography. Ann. Int. Med. 58: 870, 1961. 34) Klats, M.B. et al: Oil embolism in Lymphangiography: Incidence manifestations and mechanism. Radiology 80, 194, 1963. 35) Ditchek, T. et al: Lymphadenography in normal subjects. Radiology 80, 175, $1963 . \quad 36$ ) Weissleder, $H$. et al: Diagnostische Probreme bei der Lymphangioadenographie: Fortschritte auf dem Röntgenstrahled und der Nuhlearmedizin Diagnostik physik Biologie, Therapie 100, 80, 1964. 37) Lang, E.K.: Demonstration of Blockage and Involvement of pelvic lymphatic system of tumor with lymphangiography Scintiscanograms. Radiology (Am) 74, 71, 1964. 38) S. Chioppa G. Galli et al: Lymphadenography with Radioactive contrast medium Retroperitoneal localization of malignant lymphogranuloma. Am J. Roentgen, 92, 134, 1964. 39) A. Rittimann et al: Die Lymphographie mit öligen Kontrastmittel. Fortschritte auf dem gebiete der Röntgenstrahlen und der Nuklear medizin 97, 552, 1962.

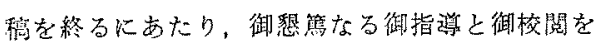
睗りました恩師三吉康郎教授に霔心より感謝の意を

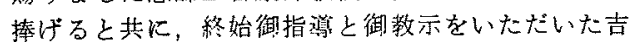

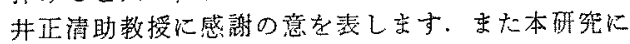
あたり热心なる御協力を頂いた中村壆博士，八谷澋 紀技師に愿く御礼申し上げ⿱す十冖゙.

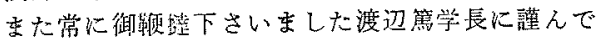
感謝致します。

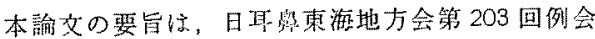
(1964)，第 206 回例会 (1965) 第211回例会（1966） に㨟いて発表した。

（原熦到滰＝昭和 42.3 .17 日） 